\title{
How Do Managers Make Sense of Their Crisis? Disrupted Relationships and Rediscovering Co-existence
}

\author{
Michal Müller ${ }^{1}$ D $\cdot$ Lenka Jedličková $^{2} \cdot$ Dagmar Halová $^{1}$
}

Received: 12 August 2021 / Revised: 12 January 2022 / Accepted: 13 January 2022

(c) The Author(s), under exclusive licence to Springer Nature Switzerland AG 2022

\begin{abstract}
Managerial work is associated with the experience of critical situations that affect not only the work performance of managers, but also their daily lives. This study presents the results of extensive qualitative research that examines, through interpretative phenomenological analysis and existential hermeneutic phenomenology, how managers make sense of their crises and other specifics disrupting their daily practice and personal lives. An existentialphenomenological approach based on the idea of co-existence - relating to the world and to self through interpersonal relationships - provides a useful framework for interpreting the lived experience of managers within the transformative process related to their identity and modes of being. Research shows that critical moments are often associated with disrupted interpersonal relationships. These can be analysed in several existential categories, such as work, struggle, play, love, and death. This article points out the fact that critical situations are inherent in managerial work and provides a novel philosophical understanding of the importance of interpersonal relationships to overcome these challenging crises. The article provides a model of managerial self-development that is extended to include the level of existential disruptions - critical situations that lead managers to question their being a manager. It is the personal crisis that is significant in initiating a new process of meaning-making, which gives rise to a new managerial self-concept that is the basis for self-development.
\end{abstract}

Keywords Existential perspective $\cdot$ Human relations · Managerial crisis · Qualitative research $\cdot$ Self-development

Michal Müller

michal.muller@upol.cz

1 Department of Economic and Managerial Studies, Faculty of Arts, Palacký University Olomouc, Křížkovského 12, 77900 Olomouc, Czech Republic

2 Department of Sociology, Andragogy and Cultural Anthropology, Faculty of Arts, Palacký University Olomouc, Tř. Svobody 686/26, 77900 Olomouc, Czech Republic 


\section{Introduction}

Although more and more research points to the fact that managers are confronted with critical situations (Lee \& Cummings, 2008; Mackie et al., 2001; Wong \& Spence Laschinger, 2015) that are the causes of many obstacles at work, there is not enough research focused on how managers make sense of these situations. It is this information, and a deeper understanding of the lived experience, that can help reveal the basic mechanisms in the origin and course of critical situations and the ways in which managers deal with them. Many crises are related to disruptions in interpersonal relationships (Harlos, 2010), barriers to communication (Harvey \& Harris, 2010), burnout feelings (Campbell et al., 2013), and other circumstances (Sveningsson \& Alvesson, 2003) associated with demanding work. In existential rhetoric, we could say that it is a fall into a stereotypical inauthentic experience, where the manager becomes a mere work role and is unable to interact with other people at all levels related to their human side - to their being (Heidegger, 2001).

The aim of this article is to partially fill this gap and point out the importance of analysing the lived experience of critical situations. This goal is fulfilled by answering two main research questions:

1. How do managers make sense of critical situations - existential disruptions - in their practice? (Section: Second movement of existence)

2. How do these crises relate to disruptions in interpersonal relationships? (Section: Second movement of existence)

3. In what categories are these relationships disrupted? (Section: Second movement of existence)

4. How do managers overcome these existential disruptions within a transformative process related to the modes of being (movements of existence)? (Sections: Third movement of existence; Implication for managerial self-development)

The methodological and interpretive level of research is based on the existentially oriented approach to management described in the first section of the article - conceptual background. The research builds on the original use of the philosophy of Jan Patočka and Eugen Fink (Müller \& Jedličková, 2020; Jedličková et al., 2021) that is useful to dynamically capture interpersonal relationships and to analyse the phases associated while experiencing the crisis. The next section introduces methodology for qualitative research and presents characteristics of the research participants. In the following sections, the research results are presented and discussed.

\section{Conceptual Background}

\section{Making Sense of Personal Crisis vs. Sensemaking of Crisis}

Before introducing the research perspective and theoretical background of the research, it is necessary to point out how the background of our approach differs from a related type of research, which is sensemaking in organizations based on the work of Weick $(1988,1995)$. Weick's sensemaking perspective represents an alternative approach to organization theory. It is a way of analysing organizational behaviour and in particular the social-psychological 
processes that are necessary to achieve outcomes in organization (Helms Mills et al., 2010). In their philosophical analysis of Weick's approach, Langenberg and Wesseling (2016, p. 223) show that Weick's conception of organization can be compared to "jazz improvisation". Indeed, it is a kind of mental model, a social construct that leads to a better representation of the true nature of the organization and its dynamics taking place within a shared meaning. As Maitlis and Sonenshein (2010, p. 551) mention, sensemaking can be understood as "the process of social construction that occurs when discrepant cues interrupt individuals' ongoing activity and involves the retrospective development of plausible meanings that rationalize what people are doing".

Authors who critically engage with Weick's work mention a possible combination of the approach with existential phenomenology. Langenberg and Wesseling (2016, p. 222) note that although Weick refers to philosophy sporadically, his conception relates to philosophical insights that can be derived and point to parallels between Heidegger's work and Weick's retrospective sensemaking. Holt and Cornelissen (2014) suggest that Weick's sensemaking perspective is implicitly based on Heidegger (2001) phenomenology. Existential phenomenology, as Sandberg and Tsoukas $(2014,2020)$ mention, helps to preserve the unity of thought and action, avoiding the separation of subjects from objects, equipping us with a promising ontology.

Segal (2017) also views Weick's work through an existential prism. Although Segal sees some similarities when comparing the existential perspective and Weick's approach, he concludes that "while Weick accounts for living backward, he does not offer an adequate account of the flux and flow of the existential dimensions involved in lived experience involved in living forward".

Our research is not concerned with collective sensemaking in organizations but focuses on how managers make sense of their critical experience - existential disruption - in the context of a transformative process concerning their being. We are interested in how they make sense of their critical experience - and themselves - which are questions about the nature of their being managers and human beings. In our research, it is personal meaning that is critical to the formation of the manager's self-concept, which has practical implications for managers' self-development. Our approach is briefly described in the following sections. Those interested in a complete methodological and theoretical guide to this type of research can familiarize themselves with the article by Jedličková et al. (2021).

\section{Existential Perspective of Management}

Both management academics and practitioners are increasingly aware of the importance of interpersonal relationships and the fact that human beings cannot be reduced to a mere workforce. We find that the roots of these ideas were already known during the 1960s, when prominent management theorists began to realize that the positivist picture of reality that was the basis for management at the beginning of the century was not entirely sufficient. An example of these tendencies is an article by Odiorne (1966), who draws attention to the diverse approaches in management that are a rather confusing mix of ideas without a unifying thread. Odiorne's approach, recognizing the existential position of a manager who is forced to constantly come up with new solutions to complex problems and so undergoes recurring crises, could be characterized as an idea emerging across current alternative approaches to management. Theoretical concepts and practical advice that emphasizes this existential level could be described as existential management. 
Existential management finds inspiration in the core values and insights of existentially oriented philosophies that emphasize the value of human existence and the existential self. This can be used in organizational theory to analyse behaviour and ethical assumptions within an organization (see MacMillan et al., 2012). Existential philosophy of management provides insights into the creative process of becoming a manager, and existential values offer a framework for "self-development through understanding and reflection of the major work-related obstacles that are directly connected with the identity of a manager and his or her being" (Müller \& Kubátová, 2021). Currently, the existential perspective is mainly used by management experts who apply the ideas of Heidegger's existential Dasein analysis (Bolle, 2006; Segal, 2010; Van de Hoorn $\&$ Whitty, 2015) or combine existential sets of values and insights with the systems approach (Kelly \& Kelly, 1998).

In the context of the crisis related to the COVID-19 pandemic, there is a renaissance of existentially oriented approaches to management. The very nature of the crisis, associated with fundamental existential problems, issues of life, death, and the effective organization of a number of necessary actions leading to the protection of human health, directly encourages the recognition of the link between existential philosophy and crisis situations (see, for example, Vandekerckhove, 2020). The relentless struggle against a pandemic, the ever recurring need to solve new problems, is reminiscent of the Sisyphean struggle that an existential manager must undergo (Odiorne, 1966). As Müller (2021a) shows, these motives and reflections on the relationship between management and the existential approach directly refer to the work by Albert Camus, who provides a framework for understanding the situation of a manager facing repeated challenges and crises. Similarly, the managers whose lived experiences are analysed in this study face constantly recurring crises - difficult moments and disrupted practice.

\section{Movements of Existence}

Heidegger's existential Dasein analysis was followed by prominent phenomenologist Jan Patočka, who, unlike Heidegger, emphasized an important aspect of human existence - intersubjectivity. This is crucial for all three stages of his original concept of the three movements of human existence. They are called (1) the movement of acceptance, (2) the movement of defence, and (3) the movement of truth. These movements are dialectically connected.

The first two movements are characterized by anchoring in existing traditions, adopting rules, dealing with things in the world, and producing them. In the community of the second movement, we are anonymous, we do not act for ourselves, and we only hold the roles that were assigned to us (Patočka, 1998).

Patočka calls the third movement the movement of truth or self-transcendence. Here man no longer relates to things in the world but to other people who man is forced to act with. The concept of action is the central concept taken from Aristotle. Dealing with other people is always uncertain, we never know its end in advance, and we give the other a chance. We have to reckon with anything, and it can happen that we can lose everything, even our lives. Just realizing our finiteness and integrating it into our existence is the most important thing that helps us get into the third movement of existence and be authentic. Authentic existence is no longer calculable, and man no longer holds a social role. Here, each person is really themselves (Patočka, 1998). 


\section{Co-existence}

The key term in the philosophy of Heidegger's next follower, the German phenomenologist Eugen Fink, is co-existence (Fink, 1969). Fink revised Heidegger's approach to Dasein because he emphasized the intersubjective aspect of human life. Man is not only an existence, but in all circumstances each person is always a co-existence that manifests itself in all the categories that Fink uses to define a person. They are work, fight, love, play, and death (Fink, 1979). These co-existentials are interconnected, and in each of them, man is connected to other people. It is not possible to step out of co-existence, to relate to the world as a whole (the most important term in Fink's cosmology) in isolation. Man, Dasein, is a relationship. And this fact must be taken into account in every situation, just as it must be taken into account when analysing human existence.

We characterize individual categories (co-existentials) in the course of the article with specific examples. Now it is necessary to emphasize the fact that the concept of action, Aristotelian praxis, is also an important concept of Fink's philosophy. He formulates this fact in his philosophy of education (Fink, 1992), which can only become a way out of nihilism and its related loss of value and meaning (Fink found the roots of nihilism in Platonic-Christian morality, culminating in the "death of God" by Friedrich Nietzsche) (Fink, 2003). By acting, we relate to the world and especially to other people; we interact with each other, and through interaction, we create new meanings and new values.

It is meaningfulness and interpersonal relationships that are increasingly discussed in the context of management and leadership as a precondition not only for work performance and motivation, but also for mental and spiritual health, at least as a prevention against adverse psychological states such as burnout (Fry, 2003; Leiter \& Maslach, 2005; Michaelson et al., 2013; Pratt \& Ashforth, 2003). Distinguishing between the movements of existence and the basic categories that relationships are realized in will allow us to understand how managers make sense of the causes of critical situations that they experience during their practice.

\section{Methods}

\section{Study Design}

This study is based on a qualitative approach to interpretive phenomenological analysis (Smith et al., 2009) that allows capturing the lived experience of managers and provides a means of understanding how they make sense of their experience. In the context of the interpretive level, it is linked to existential hermeneutic phenomenology (Rolfe et al., 2016, 2017) rooted in Heidegger's Dasein analysis. This study employs an extended version of these qualitative approaches based on the phenomenology of Eugen Fink and Jan Patočka (Müller \& Jedličková, 2020), which allows a more detailed interpretation of interpersonal relationships.

The methodological approach used provides qualitative data to understand the managerial lived experience but is also a method that can help managers self-develop through dialogic learning (Müller \& Kubátová, 2021). As will be shown in this paper, the combination of existential hermeneutic phenomenology and interpretive phenomenological 
analysis helps participants to articulate their life story, whereby their narrative becomes the basis for a new self-concept.

Managers come to a fundamental change in their lives and work through redescription (see Jedličková et al., 2021). In this respect, previous research by Rolfe et al. (2017, pp. 742-743) builds on Rorty (1989) philosophy that highlights the importance of language, which is fundamental to the possibility of using language games for a new way of being in the world. As Müller and Jedličková (2020, p. 460) show, the qualitative can be a dialogical learning process. This process is aptly described by Cunliffe (2002, p. 36), who points out that learning can be recast as "an embodied, relational - responsive process" and that during this process, we are "struck" and also "moved to change our ways of being, speaking and acting".

\section{Research Context and Sample}

Interpretive phenomenological analysis uses a homogeneous research sample. It is essential to select participants with similar lived experiences who will be able to properly portray the phenomenon under study (Laverty, 2003; Smith et al., 2009). In this case, it is the experience of a managerial crisis. Despite the diversity of age, experience, and type of managerial position, all managers experienced a personal crisis, which is the phenomenon under study. It is this lived experience that constitutes the homogeneity of the research population, which makes it possible to discern how participants attribute meaning to their experience and to compare their meaning-making processes. Research participants were selected from researcher contact lists and on the basis of so-called snowballing that employs references from current participants. The list of participants included in the study is in Table 1. The table also lists the age of the participants, their managerial position, and the materials that were analysed in this research.

Table 1 Participants' characteristics

\begin{tabular}{lllll}
\hline No. & Name & Age & Work position & Materials \\
\hline 1 & Alex & 43 & HR director & 1 recording \\
2 & Andrea & 30 & Marketing manager & 1 recording \\
3 & Andrew & 24 & Manager in a family business (logistics, & 1 recording, field notes \\
& & & marketing, innovation, sales) & \\
4 & Anne & 29 & Training and development manager & 1 recording \\
5 & Caroline & 30 & Administrative manager & 1 recording \\
6 & Daniel & 28 & Psychologist, manager & 2 recordings, field notes \\
7 & Daniela & 38 & Development manager & 1 recording, field notes \\
8 & George & 34 & Manager in social services & 1 recording, field notes \\
9 & Kim & 26 & Property manager & 1 recording, personal \\
& & & notes, field notes \\
10 & Marie & 43 & Warehouse manager & 2 recordings, field notes \\
11 & Martin & 31 & Entrepreneur, sales manager & 1 recording \\
12 & Paul & 29 & Entrepreneur, project manager & 2 recording, field notes \\
13 & Peter & 35 & Project manager & 1 recording, field notes \\
14 & Rebecca & 43 & Manager in logistics & 1 recording, field notes \\
\hline
\end{tabular}




\section{Data Collection}

The research was based on in-depth semi-structured interviews lasting approximately 45 to $60 \mathrm{~min}$. Some participants were interviewed multiple times because of their rich lived experience. Furthermore, field notes were taken based on further communication with respondents. Some participants also provided their own notes where they expressed some additional information regarding their experiences. All recordings were transcribed and analysed together with other materials. Each research participant signed an informed consent to participate in the research and to make a recording. All materials have been anonymized; for this reason, the names used in the text are fictitious (pseudonyms). Participants in the interview described their life story related to their career and were directed by the researchers with additional questions related to their personal crisis experience to uncover their lived experience and the meaning they attribute to their disrupted practice. Attention was directed to the emotions of the research participants. For a detailed description of the research framework, including interview questions, see the methodology paper by Jedličková et al. (2021).

\section{Analysis}

Interview analysis is based on multiple hermeneutic cycles. The transcribed interviews are read several times by researchers and analysed according to the recommendations by Smith et al. (2009). Emerging themes are found during this reading and commenting stage. Pilot in-depth studies based on several months of research supplemented by field notes helped modify the interpretive framework. Two phases of the existential situation - the "second movement of existence" concerning the inauthentic and anonymous being leading to the crisis based on disrupted interpersonal relationships and the "third movement of existence" related to redescribing the situation and overcoming the crisis - proved to be suitable topics for deeper analysis and represent emergent themes across studies. The analysis of interpersonal relationships then uses the categories defined by Fink (1969), namely work, struggle, play, love, and death. Knowledge of these categories is then synthesized to help create a model of lived experience related to the formation of meaning in the critical moments and interpersonal relationships that are key to overcoming difficult periods. This model then helps understand the facts as a whole, which has practical implications for management. The following sections describe the results of the research, first the critical situations related to the second movement and then the rediscovery of the importance of interpersonal relationships that concerns the third movement.

\section{Second Movement of Existence}

This section presents the results of analysing the managers who find themselves in an existential situation from the second movement. This situation is characterized by reducing the managers to their mere roles. In their relationships with others, they act anonymously and only in the context of work tasks (Patočka, 1998). First, the experience of that inauthentic being is introduced, then the experience of crisis, and then the disrupted practice will be articulated as problems with co-existence. 


\section{Inauthenticity and Being in Convection}

Every community of people, including the workplace, has its own rules, customs, and traditions that are necessary to exist. The problem, however, arises when these behaviours reduce individual human beings - and the relationships between them - to mere roles and routine tasks.

Although managerial work may be perceived as meaningful, it often happens that most tasks are associated with routine administrative work (Table 2: Ala-b, C1a-c, K1a-b). This stereotype, habitual ways of doing work, also applies to other managerial functions and organizational activities. In most cases, this fall into inauthentic experience is associated with extreme work commitment. Initial enthusiasm for work and responsibility are replaced by neutral emotions and exhaustion (Table 2: D1a-c, Pe1a-d). The problems and conflicts that the manager has to solve are constantly repeated (Table 2: Da1a-c). This cyclicality - the constant repetition of the existential situation of the manager - is a frequent experience (Table 2: Ann1a-b, P1a-c).

The experience of a stereotype can also be expressed by an increased desire to leave the workplace. The manager is only considered part of the management processes and is not allowed to develop their skills (Table 2: An1a-d). Another possibility is that they want to push for change, but in a given environment, it is impossible (Table 2: M1a-d, And1a-d). Repetition of the situation can also be at the level of constant change in job positions, where the situation is equally exacerbated and the manager voluntarily, or sometimes forcibly, leaves (Table 2: R1a-f).

Inauthentic experience can also be caused by long-duration projects without clear results. Managers are then forced to exert excessive effort to complete the activities they have begun, especially when they have to work on new activities (Table 2: Mala-c, Pe1a-d).

However, a certain degree of stereotypical work is necessary to organize work activities for employees. The manager's task is to find a balance between regularity and authentic experience within their function that will not degrade them to a mere unit within the system (Table 2: G1a-c).

\section{Crisis and Existential Disruptions}

Adapting to conditions and developing tools and reusable mechanisms to manage an organization are sooner or later disrupted by a critical situation. This critical situation can have several causes. In the context of the dynamic nature of business associated with confrontation, with uncertain conditions, and an unpredictable environment, persistent success is a mere illusion (see Odiorne, 1966; Vandyshev, 2015). The very stereotype and being in convention, together with the pressure for constant performance, can act as the cause of the incipient crisis, and it can then increase the influence of other obstacles. All these situations connect interpersonal relationships, because we relate to the world and to ourselves through other people (Fink, 1979). The description of disrupted practice in the context of interpersonal relationships is analysed in the following section. This section shows the initial feelings related to existential disruptions that managers experience when their habitual ways of doing things are threatened (see Müller, 2019; Müller et al., 2021; Rolfe et al., 2016, 2017). It is an experience that is not yet sufficiently reflected by managers, and they do not realize the deeper connection with relationships and with other people. 


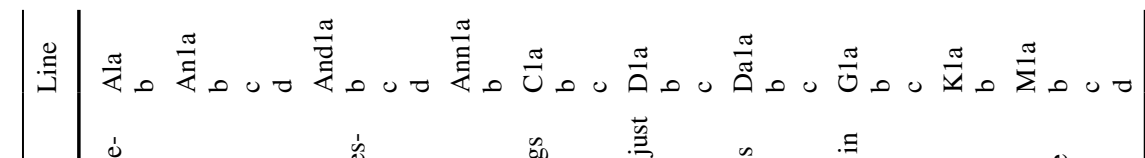

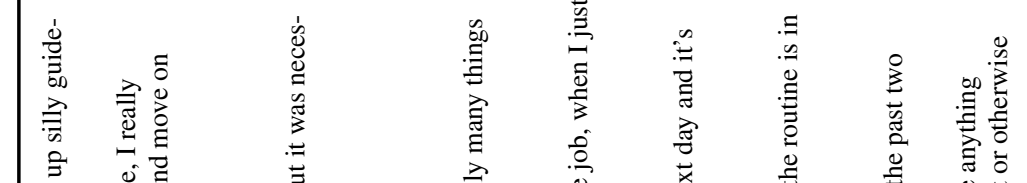

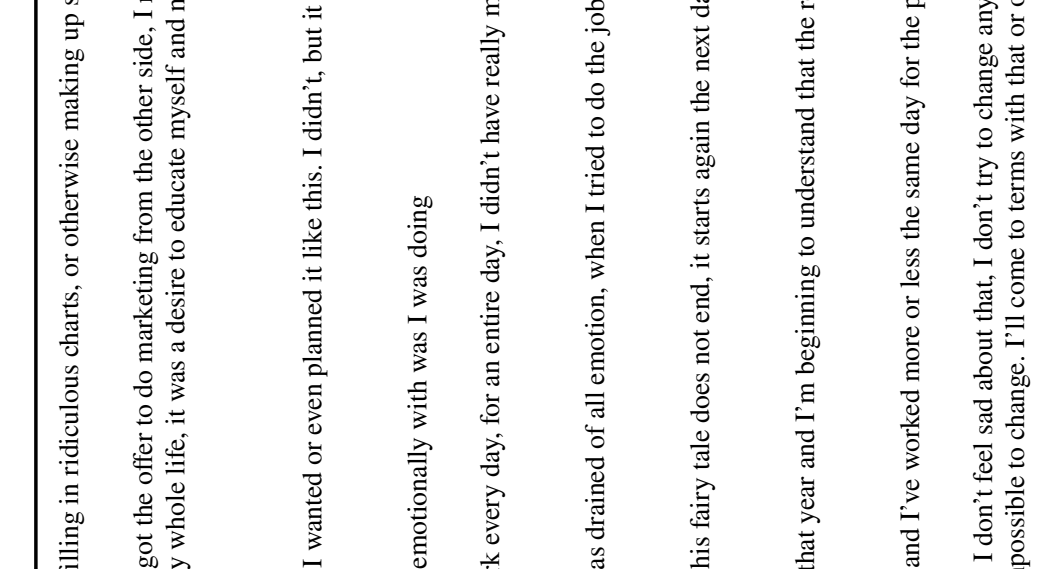

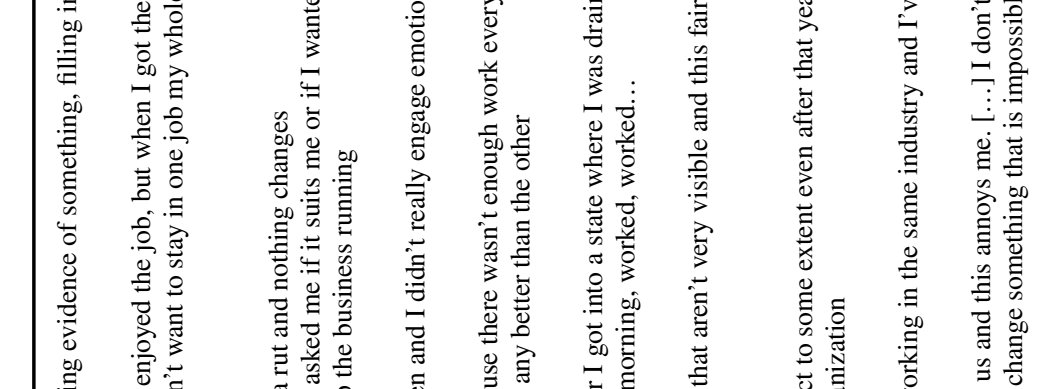

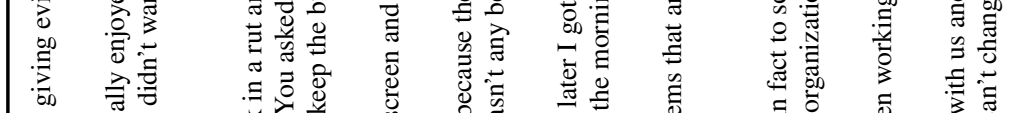

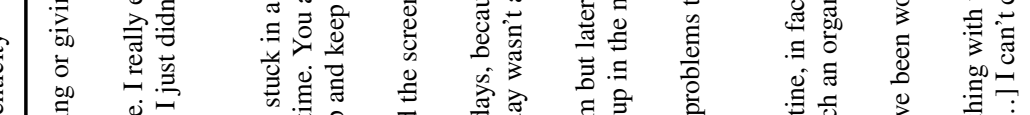

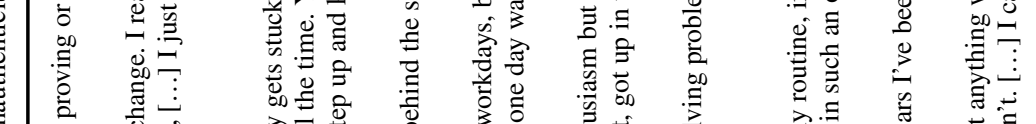

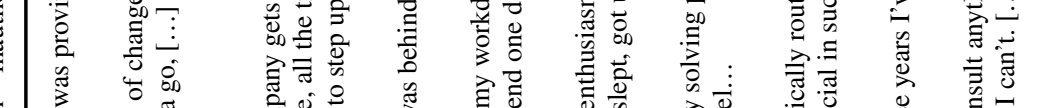

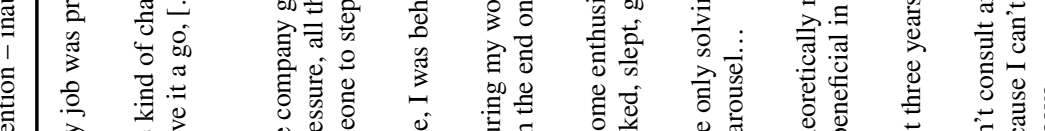

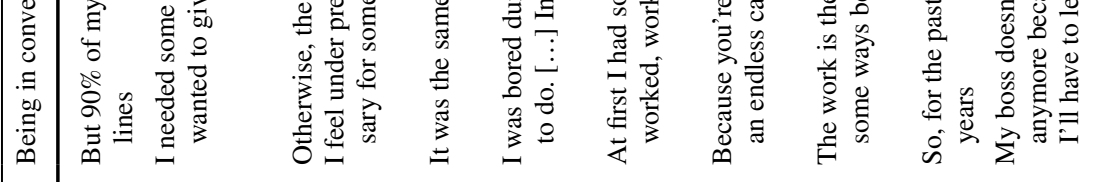

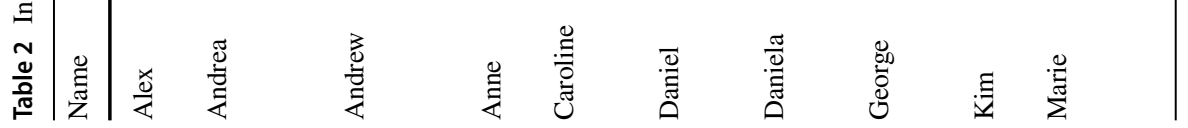




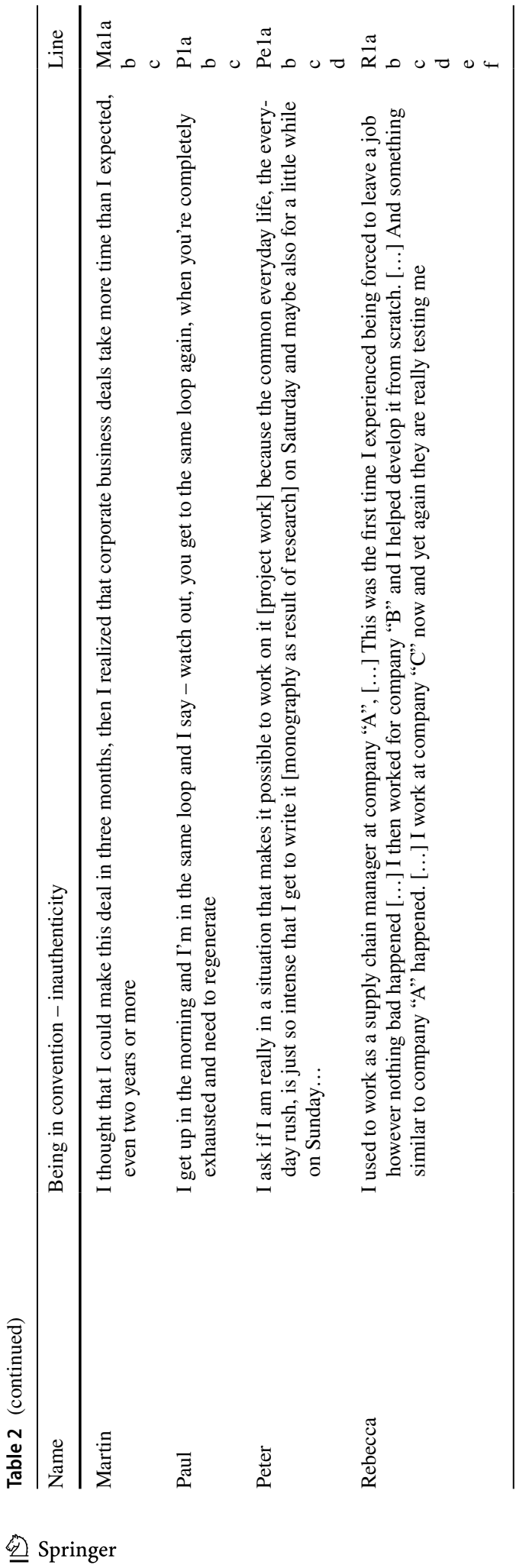


Lived experience related to critical situations shows different severity levels in the impact on the mental and physical condition of managers. In some respects, these moments can be considered a pre-phase of burnout that could occur in cases where managers have long-term exposure to the situation (see Müller, 2019). Unlike burnout syndrome, however, managers do not resign themselves to their managerial identity, they continue to self-develop and still have a desire to do their job. However, critical moments lead to very psychologically demanding moments, as shown by the cases of Alex, Caroline, and Anne, whose mental states are very close to burnout (Table 3: A1a-c, C1a-b, Ann1a-b).

Managers are often reduced to their roles by their superiors in top management or the owners of the organizations. Continuous conflict with superiors is described by Andrea, Marie, Caroline, Daniel, George, and Rebecca. From their job positions, they cannot fulfil their potential and enforce changes in the organization (Table 3: M1c-d, G1a, G2a-b). They adapt to the rules of the game (Table 3: C1a, G1b-c) which can only suit them for a short while. Before the first critical moments, failure or an exchange of views with the owners appear (Table 3: An1c-d). The joy of work disappears, and feelings are rather neutral (Table 3: D1a-c). At the same time, there is an uncertainty about the future (Table 3: R1a-f, K1a-b, Pe1a-b).

Alternatively, it may be a family conflict within a family business, where managerial roles are not sufficiently defined, as shown by the cases of Daniela (Table 3: Da1a-e) and Andrew (Table 3: And1a-c).

Cyclicality in the form of a constant fall into recurring failure causes frustration that can lead to the experience of depressive states, as shown in the case of Paul (Table 3: P2a). Martin even mentions suicidal thoughts (Table 8: Ma). However, both have enough strength to bounce back from the bottom and move on. Awareness of the causes of these problems - recognizing that these are disrupted interpersonal relationships, however - is a long-term process requiring self-reflection.

Managerial work that falls into the conventional way of being can also be characterized by a lack of social contact. First, there may be management activities in the online environment, as was the case with Anne. This topic seems to be important in the context of current work from home trends due to the coronavirus pandemic. The excess of work activities without sufficient social support also caught Peter, who feels physically and mentally at the bottom (Table 3: Pe1a-c).

It is obvious that even in these descriptions of emotions we find the topic of relationships with other people. Managers are treated anonymously; they are not treated as complete human beings who need feedback and space to deal with difficult situations requiring ever new solutions. Hard work and incoming problems prevent them from realizing that not only their work efforts and traditional ways of working are disrupted, but also their relationships.

\section{Articulating Disruptions as Problems with Co-existence}

Work Work is an important activity, not only because we spend a lot of time doing it, but also because it determines our relationship with the world. The world is a product of our work because we produce new creations and cultivate ourselves and our surroundings. This is not possible without our various ties and relationships being intertwined (Arendt, 2018; Patočka, 1998). 


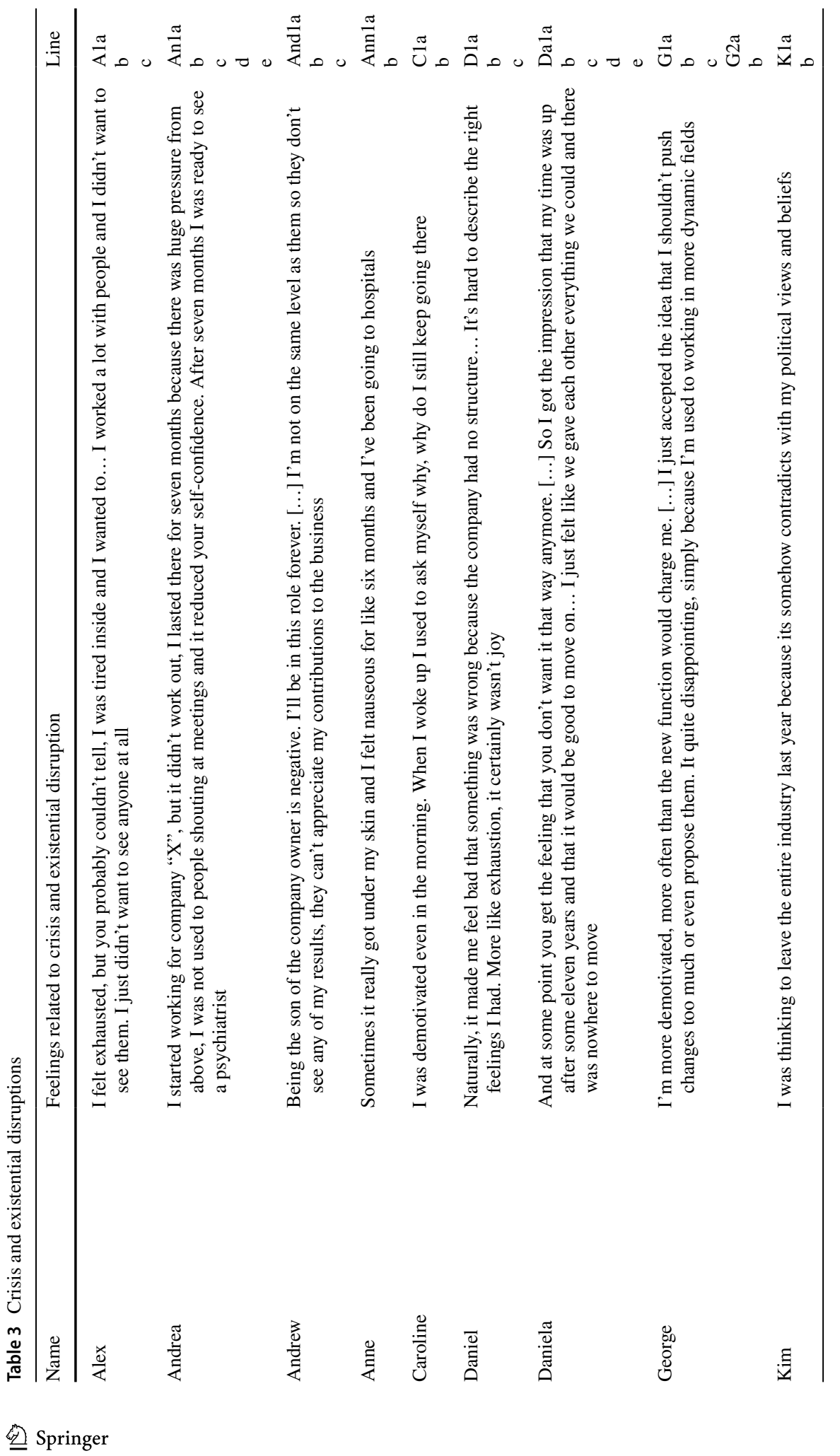




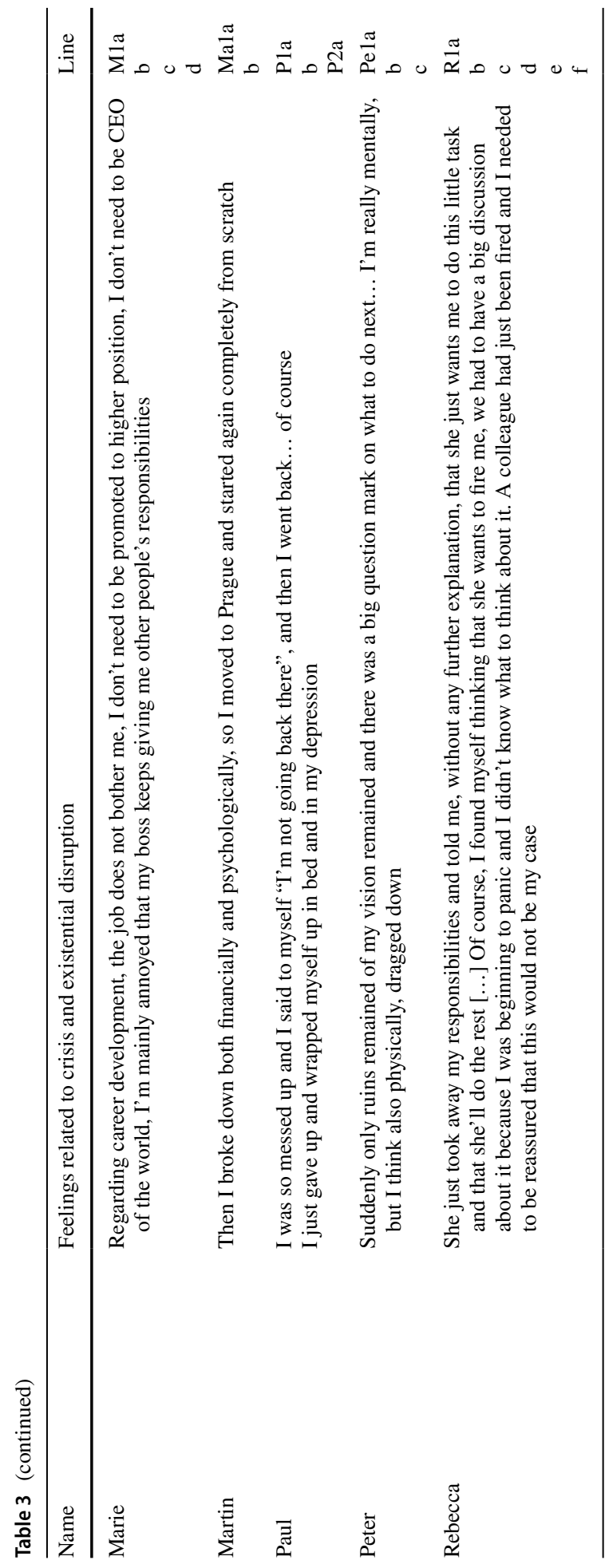


Managers become part of the companies where they work - they want to help develop the company, the company's environment, and their own skills. However, they begin to realize that they find themselves in a network of relationships that are not always what they want. HR director Alex finds that the communication channels between top management and middle management are set up incorrectly, resulting in tasks not being clearly defined (Table 4: A1a-d). Daniel struggles with poor communication. He even describes the owner of the company as very aggressive (Table 4: D1a-d). George faces communication problems. Caroline and Marie do not have good relationships with business owners. In addition, the owners of the companies are their direct superiors, so they do not see any possibility of promotion in the structure of the company or even for personal development (Table 4: G1a-c, C1a-c, M1a-c). Rebecca (Table 4: R1a-c) points out the absence of organizational culture and insufficient leadership in top management.

Labour relations and cooperation have become a problem for Peter in his project management (Table 4: P1a-b). Paul does not build enough relationships with other people and tries to do all the work himself. He believes that hard work must lead to success, a pattern of behaviour that he adopted from his family (Table 4: P1a-c). Anne, who manages all activities online and does not have a chance to meet real people (Table 4: Ann $1 \mathrm{a}-\mathrm{c})$, encounters a similar absence of interpersonal interaction.

Martin believes that it is possible to completely distinguish two roles at work - professional and personal. He tries to enforce this approach, which costs him a lot of effort (Table 4: Ma1a-c). Kim is forced into neutrality and a ban on expressing personal political views, leading her to consider resigning. She realizes that she is not just her managerial role but a person whose being touches on several levels, not just the working level (Table 4: K1a-b). Andrew and Daniela, who are struggling with relationships in family businesses, are not very successful in setting up relationships or developing and cultivating the company. Andrew realizes how difficult it is to enforce any change (Table 4: And1a-c, Da1a-d).

Andrea realized she needed the company's work environment, and with the work she had previously done for the company as a freelancer, she started working for the company directly, where she found support from top management (Table 4: An1a-d).

A certain motif that Jan Patočka develops in his phenomenology in connection with Martin Heidegger appears explicitly or indirectly in statements from all participants. This motif relates to the perception of a discrepancy between the role of the "worker" and the person outside that role. It turns out that the relationship between the two roles is severely disrupted at the time of a crisis, often even in direct conflict. The participants themselves even point out that these two aspects of personality need to be distinguished, and often do so even consciously, in an effort to maintain balance. It can be stated that this approach is to some extent acceptable. But the problem arises when they realize that they are not "authentic" in their role as "workers" (Patočka, 1998). The work is more about mechanically performing the activity, for which, in the second level - the personal - of existence; they do not see real meaning and value. This is a problem because, aside from the fact that managers spend a substantial part of their daily lives in the role of a worker, it is primarily a tension that could also be called a broken relationship, in this case with oneself. According to Patočka, once a person becomes stuck in the second movement of existence (according to Heidegger (2001) "[he] is inauthentic") and does not try to connect this role with their real humanity in the third movement (authentic existence), they lose their meaning, and the originally solid base of work that gave them life certainty and a sense of security becomes insignificant and disappears. 


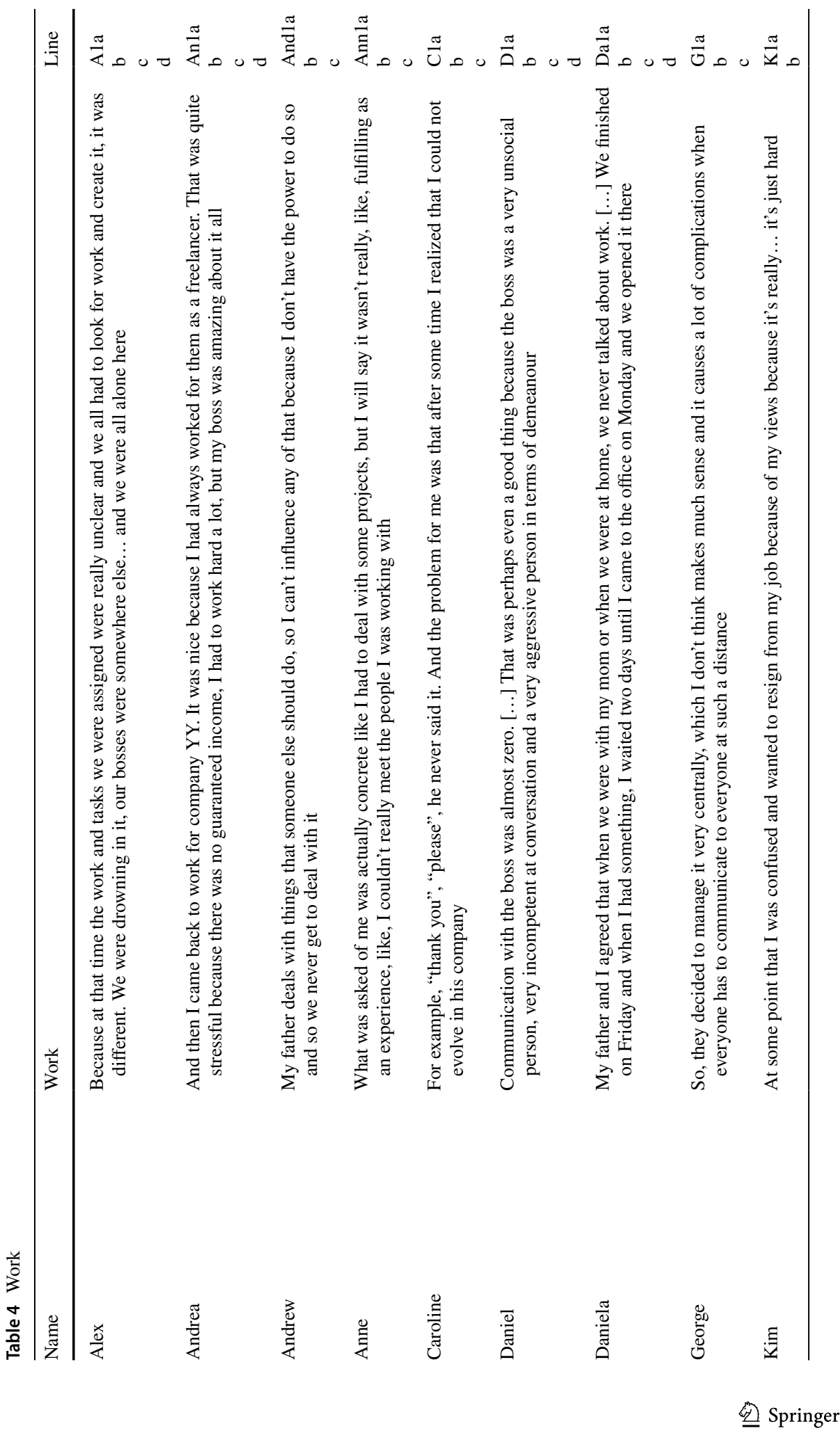




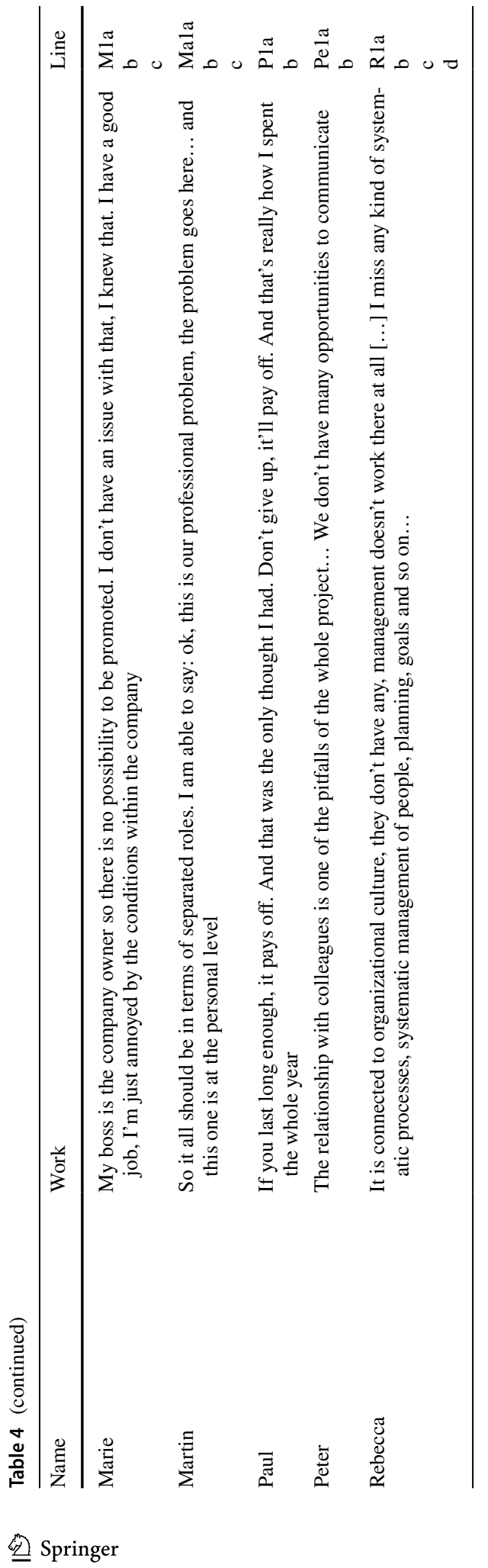


The anxiety of such a loss of "solid ground beneath one's feet" is destructive on the one hand but can be (and usually is) an impulse to find a new meaning (Patočka, 1998).

Struggle Society is often shaken by power struggles, which can be violent in nature. People are fighting for their place in the hierarchy. However, struggle is also an important element in the development of society (Fink, 1979). In addition, complex systems are difficult to imagine without hierarchy, and people need a certain order (Leavitt, 2003). In many cases, however, the fight disrupts interpersonal relationships and is very exhausting for all involved.

Alex describes how friendships at the corporation gradually turned into a power struggle (Table 5: A1a-d). Kim expresses struggle in a completely different form - an unspoken tension and constant pressure for neutrality. The real estate company of the property owner cannot express support for anti-government demonstrations in Hong Kong. She and her colleagues must not talk about it, and she can only protest in buildings that are not managed by the company (Table 5: K1a-c).

Conflict with business owners and top management is very common. Andrea has to resist the onslaught of new tasks while working from home, and Caroline, Marie, and George describe numerous quarrels at the workplace (Table 5: An1a-d, C1a-b, M1a-d, G1a-d). Daniel also experiences a conflict with the company owner. He eventually discovers that the company's actions are against his ethical values. The leadership reminds him of mafia practices (Table 5: D1a-c). Anne is afraid of conflict - she tries to avoid problems at all costs, so she is not able to ask for help to solve the difficulties she is facing. She fears she will be labelled lazy (Table 5: Ann1a-b).

Andrew and Daniela describe struggles within the family businesses (Table 5: And1a-b, Da1a-b). Paul is constantly dealing with the past, unable to find his own way. His actions are motivated by an internal family conflict - an effort to come to terms with his father (Table 5: P1a-b).

Martin describes conflicts in dealing with people. He describes two dramatically different strategies - retreating and ending the investment in a relationship with people with different ideas on the one hand and a tough argumentative struggle on the other (Table 5: Ma1a-d).

Peter describes influences from the environment - the other unknown people who influence future processes. Man is settled in a social context whether it wants to or not (Table 5: P1a-b). Rebecca describes the complexity of her tasks - a constant dynamic that must adapt (Table 5: R1a-d). From an existential concept, each meeting concerns a new case study requiring an original solution (Odiorne, 1966). Although she enjoys the work, the question arises as to whether she really needs to continue in this area of industry.

According to Fink, struggle is one of the five basic categories of human existence (Fink, 1979), but it turns out that it must be in accordance with the other four. If it prevails over the others and the struggle for power becomes the dominant existential, all relationships, including the relationship to the world and values, are naturally disrupted.

Play According to Fink (2016), the game is a symbol of the world, which is related to the fact that if we understand its rules and the space-time in which the game takes place, we will also understand the world. Alex explicitly names Fink's play category when she mentions how managers approach the rules of the game and compares them to children at the playground who take part in the competition to see who would be the better manager 


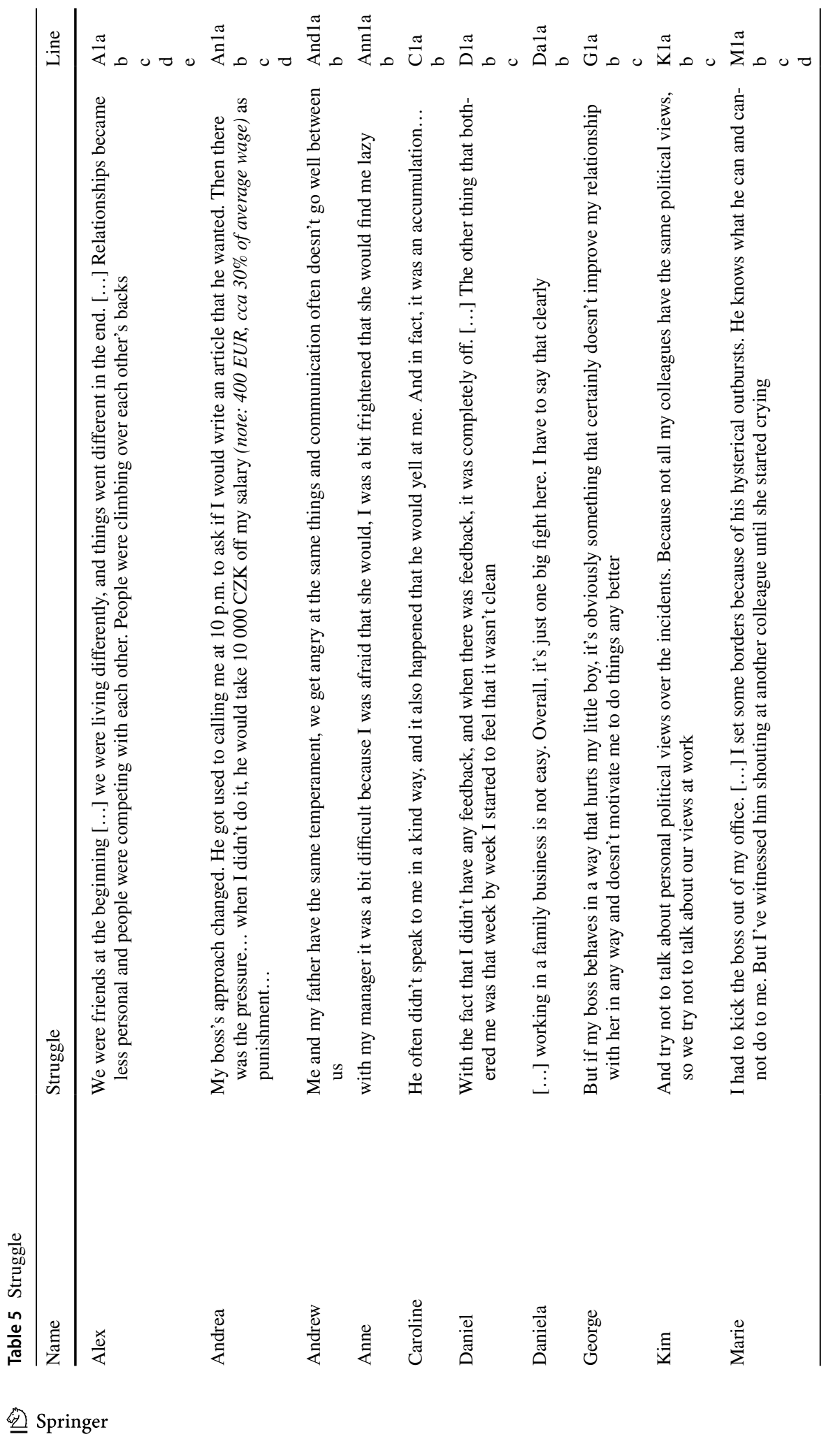




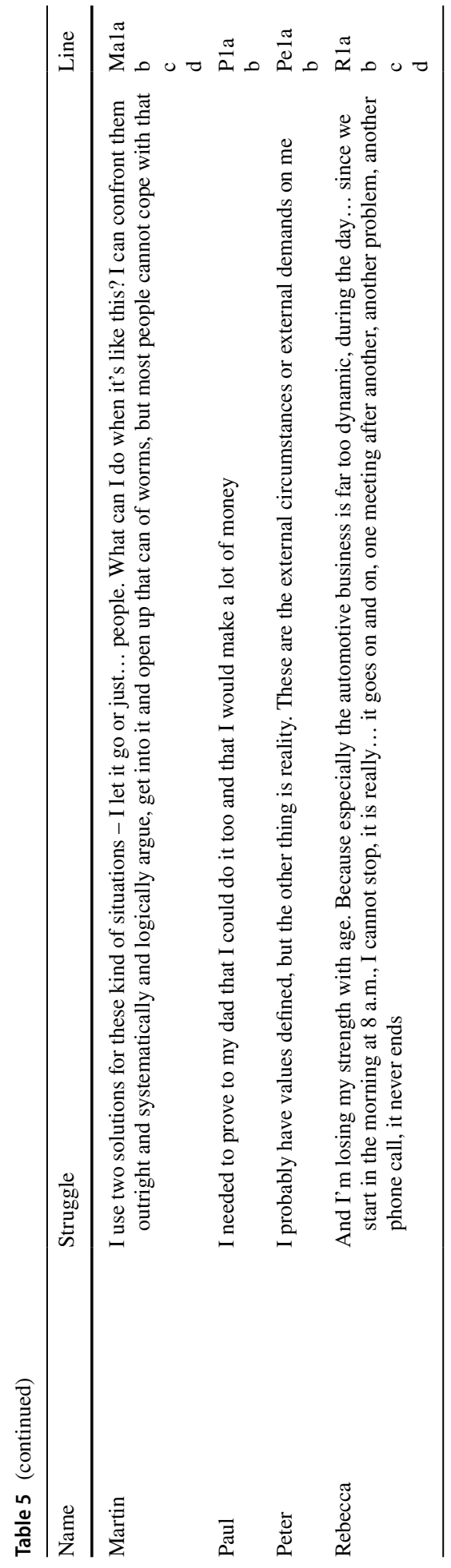


(Table 6: Ala-d). This way of playing roles is against Andrea's values. She shows that this way of playing is typical of top management (Table 7: An1a-c).

Our roles do not have to be determined only through the structure of relationships at the workplace. Some managers are forced to play the role of the manager by parental pressure, growing up in the background of a family business, and adopting family behavioural patterns. Anne chose her profession under the influence of social pressure (Table 6: Ann1a-b). Andrew and Daniela go beyond the traditions of a family business. At the same time, Andrew does not even want to be a manager because he is not ready for this role. In addition, he feels as if he is playing the role of secretary instead of manager (Table 6: And1a-d, Da1a-c). Paul adopted family patterns of behaviour that do not suit him. He tries to prove to his father that he is also able to make a lot of money (Table 6: P1a-b).

Another theme is the game in the form of manipulation. Mary describes that she finds herself in a network of distorted interpersonal relationships where people try to transfer responsibility for their mistakes to someone else (Table 6: M1a-c). Daniel, as the top manager, is manipulated by the owners of the company who want to continue their unethical business practices (Table 6: D1a-d).

Managers often have to follow rules of the game that do not suit them. They oppose their values, opinions, and political conceit. Kim cannot talk about her stance on antigovernment demonstrations in Hong Kong (Table 6: K1a-b). George is unable to enforce more stringent measures against the spread of coronavirus (Table 6: G1a-b). Caroline feels like a redundant secretary for top management (Table 6: C1a-b).

Peter is struggling with the absurd way that roles are set within the project. Although he is responsible for the main outputs of the project, he is not formally assigned as a project manager and so does not have sufficient information to manage all activities (Table 6: Pe1a-c).

All these examples have one thing in common: the phenomenon of "play" is connected here, as Fink points out, with other phenomena of human existence at the ontological level (Fink, 1979). Participants "play" at work, in love, and in struggle, and it is a natural part of our lives. But the essence of every "play" is that there are clearly set rules, the role we play in the game, the play space, and time. There is still a feeling of unreality in play; play is just "as if". This feeling is often liberating because it relieves us of some responsibility. It is nothing; it is "just" play. Our whole life is play (Table 6: R1a-d). The play area can be a work environment or a family. However, if the rules are broken, when someone exceeds their roles in the game (imagine a game of chess in which the characteristics of one game figure would suddenly change without the opponents agreeing), a crisis arises that one of the participants feels an injustice and a loss of confidence, because they cannot rely on the next steps of a teammate and cannot plan their own. The word "teammate" needs to be emphasized here. As Fink rightly points out, the essence of the game is always, in all circumstances, that it is intersubjective (Fink, 2016). There is no "play for one". Even when a child plays alone, he or she creates imaginary teammates. By breaking the rules of the game, the relationship will necessarily always be disrupted.

Love Love is another category through which we relate to other people and to the world. In management theory, biological predispositions are often forgotten, the fact that the manager is either male or female. The phenomenon of love then connects people to each other and is also important when forming family ties (Fink, 1979). 


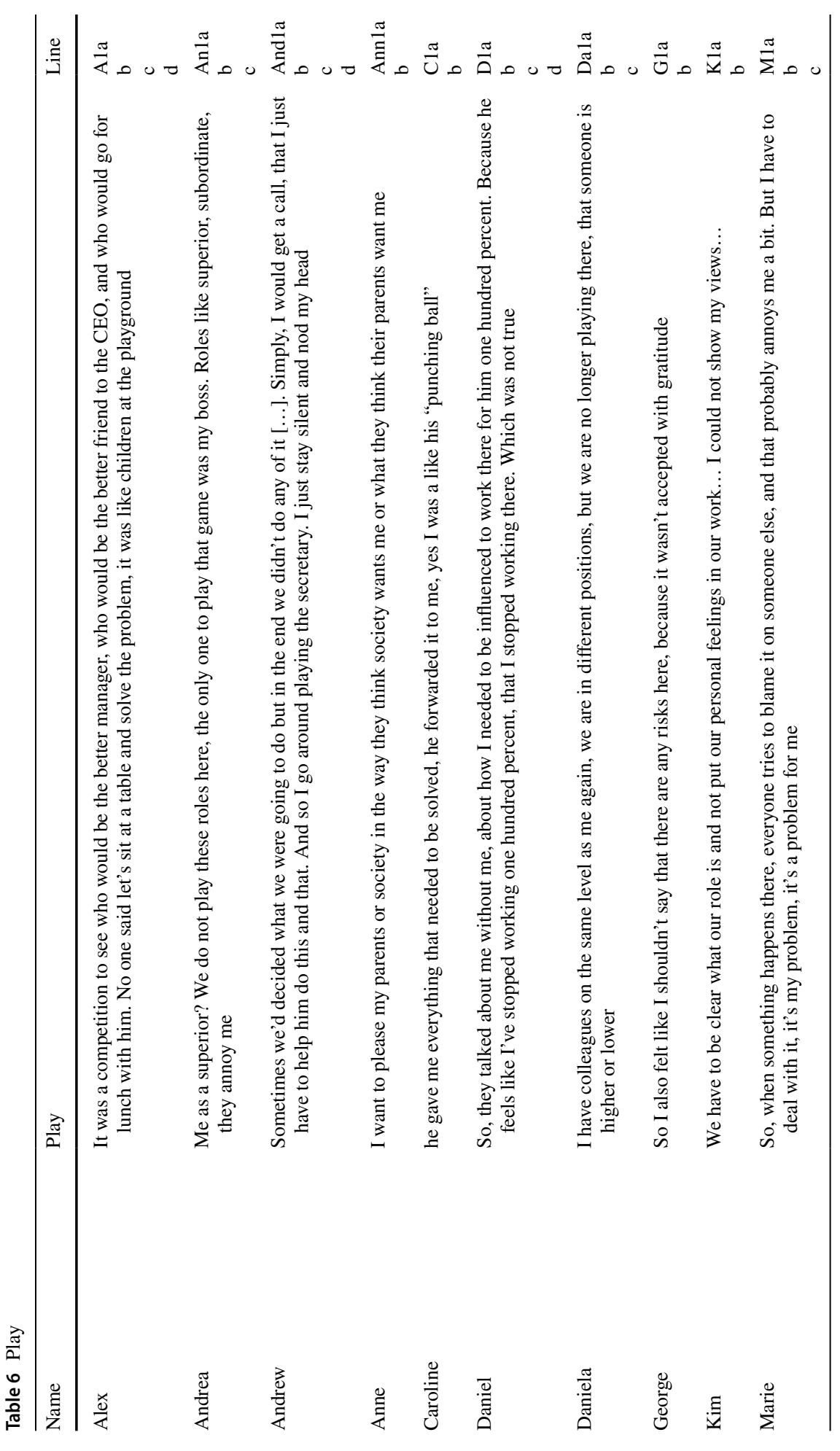




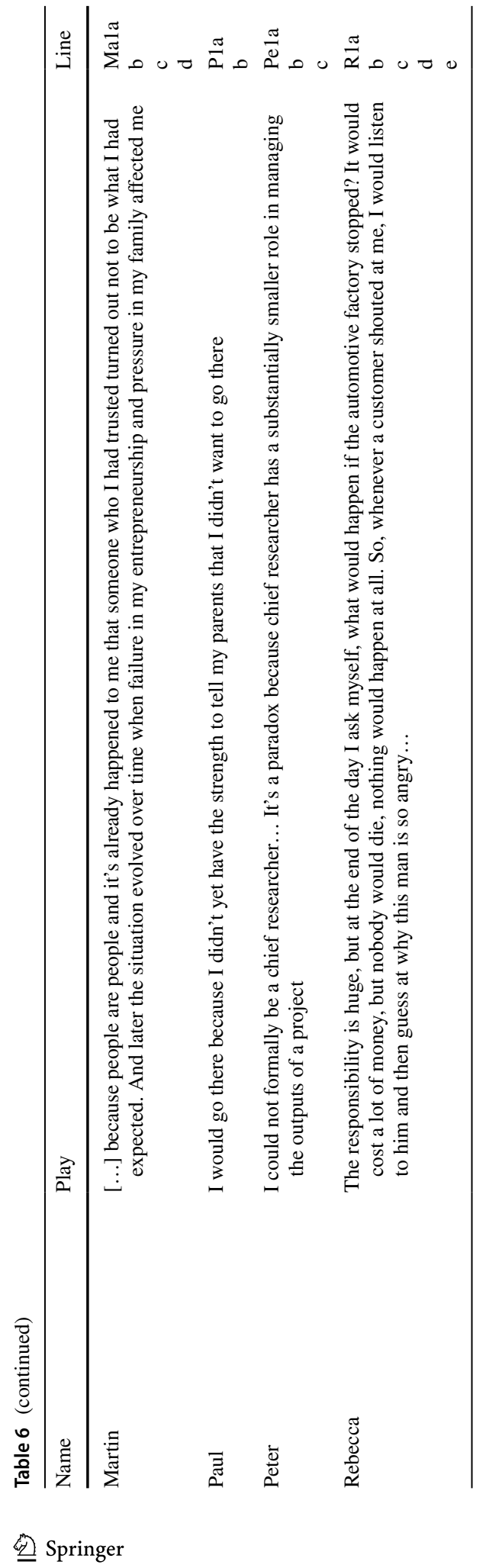




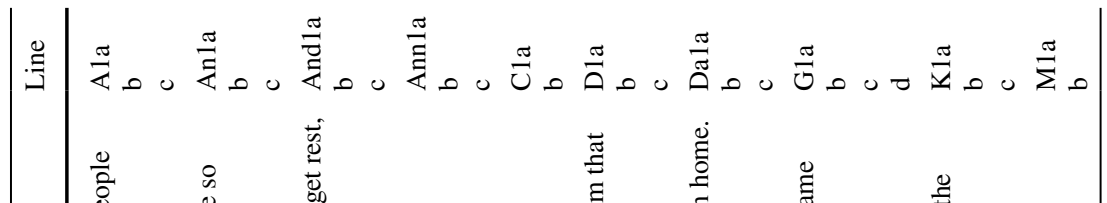

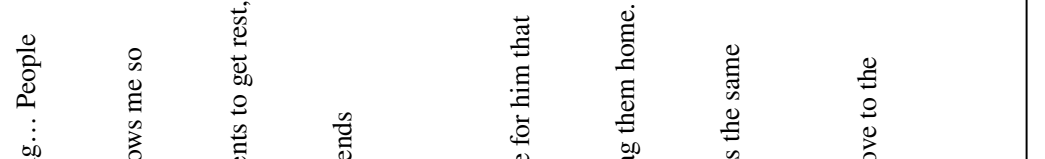

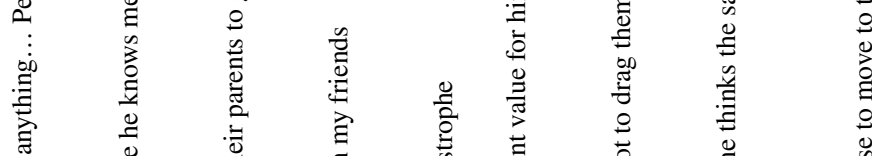

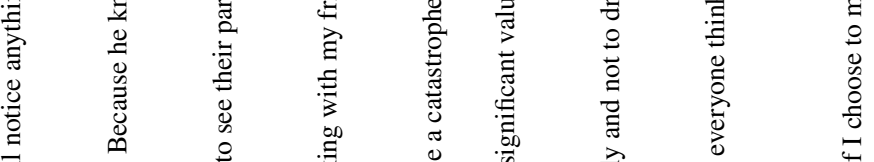

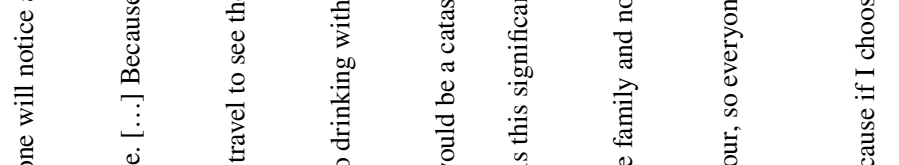

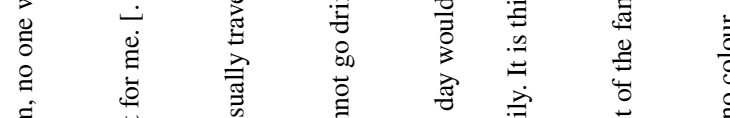

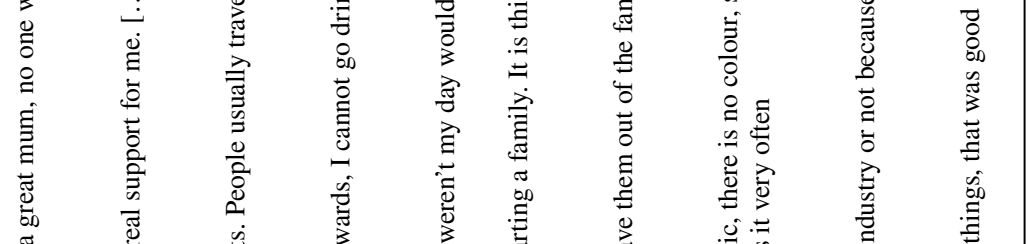

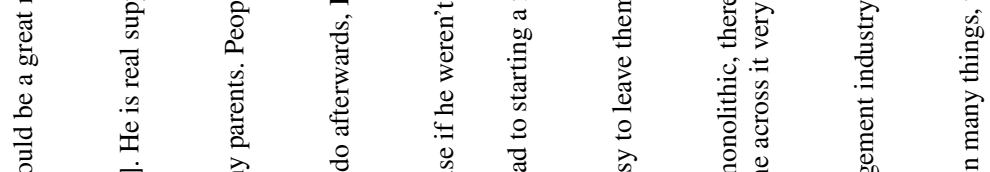

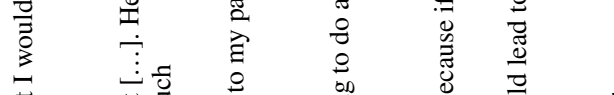

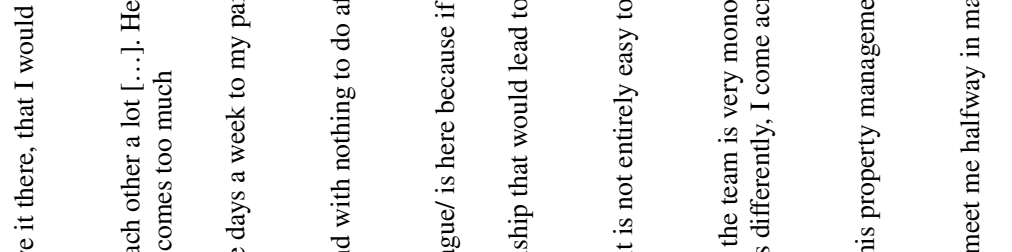

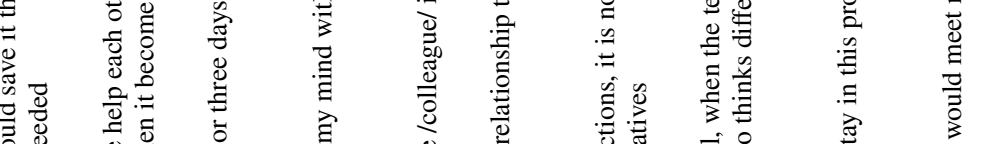

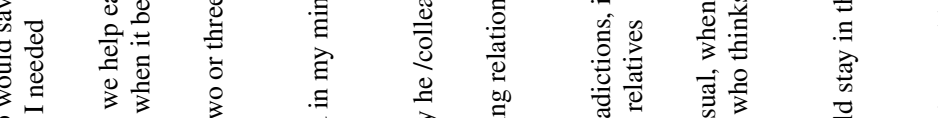

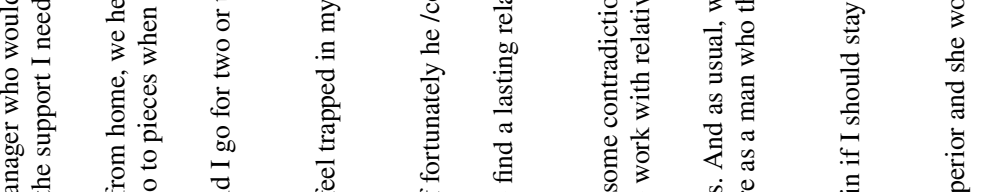

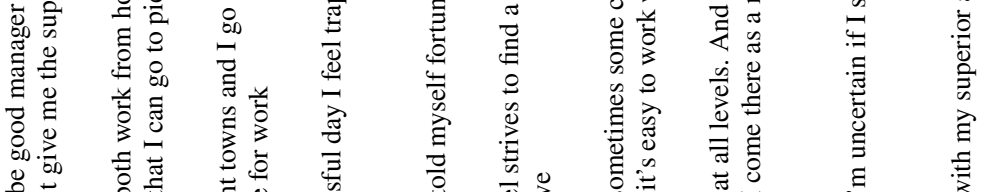

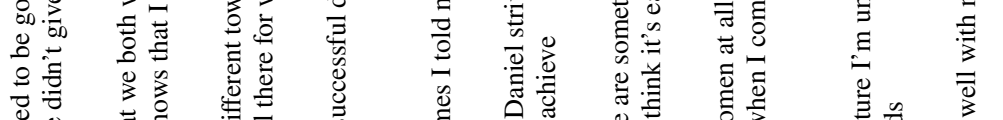

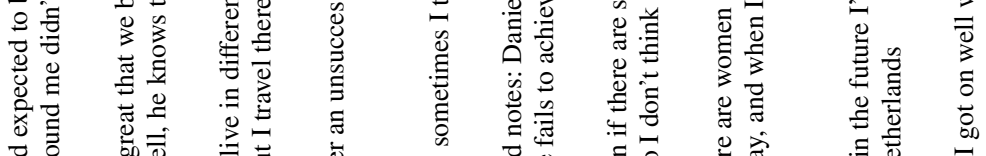

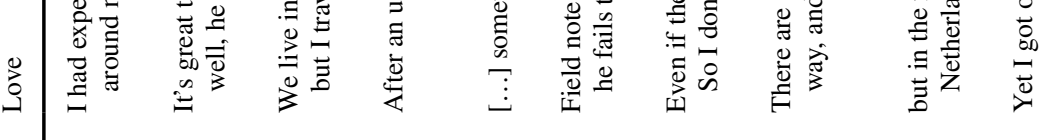

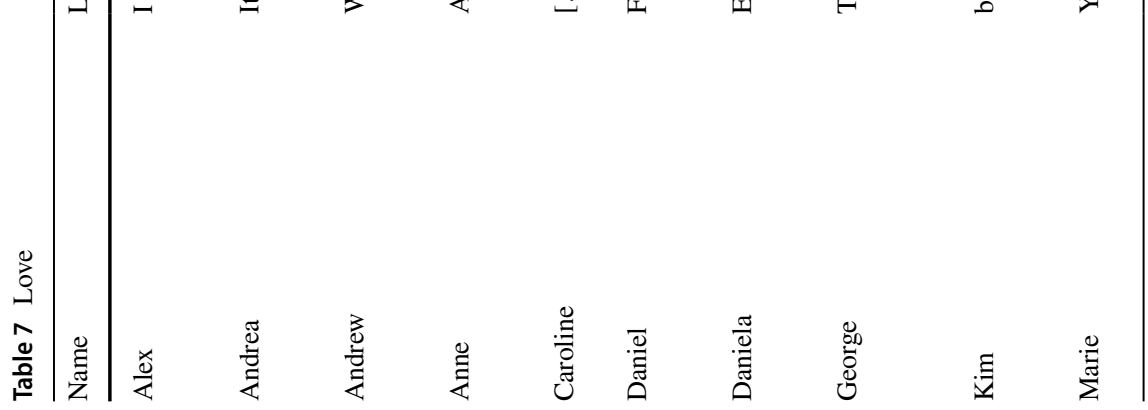




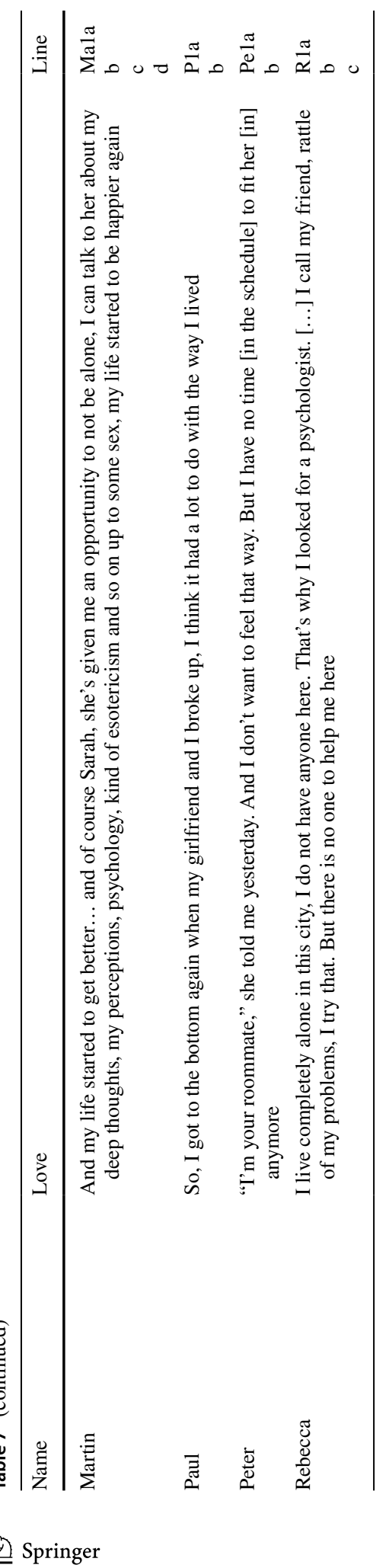


Using social support is one of the basic strategies to prevent burnout (Maslach \& Goldberg, 1998). Managers experiencing disruptions at work are aware of the importance of relationships in their lives. However, it is not just about working relationships, but also relationships with family and loved ones. Interviews with managers confirm the findings of current studies that highlight problematic relationships at the workplace (Maslach, 2017). In this difficult situation, the support of a colleague is necessary, as Marie and Caroline mention (Table 7: M1a-b, C1a-b). During the COVID crisis, Andrea found support in her boyfriend, who was also working from home (Table 7: An1a-c).

Managers do not always find social support. Alex, Anne, and Rebecca point to a lack of friends and collegial relationships (Table 7: A1a-c, Ann1a-c, R1a-c). Another problem is that work problems and the experience of the crisis cause complications in relationships. Peter describes the lack of time for his fiancée. Andrew finds himself in a similar situation. Paul admits that his focus on work was one of the reasons his relationship with his girlfriend collapsed. Daniel and Martin then experience a lack of love. Kim decided to resign and move in with her husband (Table 7: Pe1a-b, And1a-c, P1a-b, D1a-c, Ma1a-d, $\mathrm{K} 1 \mathrm{a}-\mathrm{b})$.

In connection with the phenomenon of "love", Fink emphasizes our biological predispositions, and, as it turns out, the topic of sex is still alive, not only in the field of management. Despite all efforts for "equality", it must be said that people are simply not "people" but are always predestined by their sex. Fink rightly points out that philosophy (and not only this discipline) leaves this fact aside. However, as our research shows, this fact is (mostly unspoken) present. For example, monolithic collectives prove to be a big problem, especially when a "foreign element" enters these collectives (Table 7: G1a-b).

But the phenomenon of "love" must be understood in the broadest sense of the word. It is not just a relationship in the sense of "love", but a close relationship with people around us. The first such community that provides us with protection and security is the family (Table 7: Da1a-b), from which we get out of time, but, as a solid ground for the first movement of existence, it shapes and accompanies us throughout life (Patočka, 1998). Another such group is friendships, and the disruption of any of these relationships is again reflected in all other phenomena of human existence (Fink, 1979).

Death Death is another important category, because in the existential perspective, death is the essence of human existence (Heidegger, 2001). Death is closely related to other categories as well - especially love, which is a manifestation of human finiteness. The ability to love belongs to people, and at the same time, love ensures continuity in the family, enabling the mortal to secure immortality (Fink, 1969). We see this connection in family companies, where descendants - managers - are required to continue the business tradition. But even a family business can end its existence. Andrew suggests that these claims are no longer acceptable to him and that his personal life suffers (Table 8: And1a-d).

As Alex mentions (Table 8: Ala-c), existential disruptions - especially disrupted interpersonal relationships - can lead to burnout in the long term. Alex aptly describes how managers are trapped in a constant fear that prevents them from making a change. Their existence - the need for money to secure the future - prevents them from leaving the job that is exhausting them. Daniel also describes this fact when he talks about his colleagues (Table 8: D1a-c). Alex has used her ability to redescribe the situation - and find meaning in the crisis - to start her future profession as a coach and help other managers. Andrea also describes the helplessness of the situation (Table 8: An1a-c). 


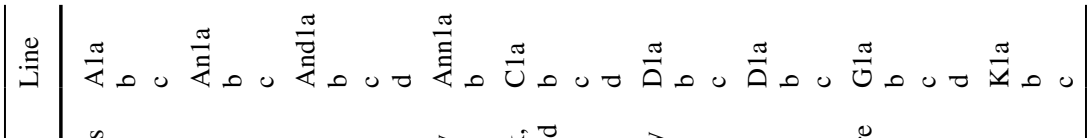

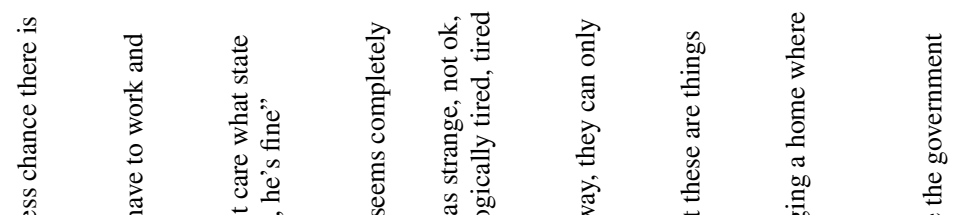

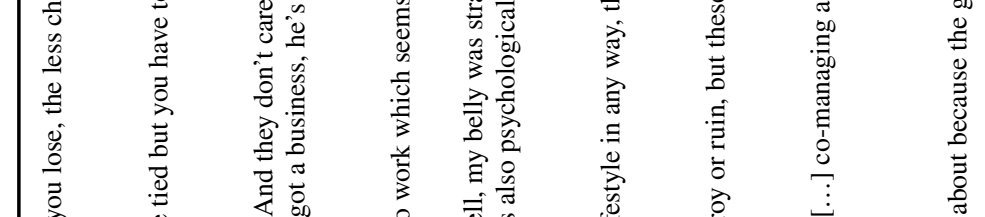

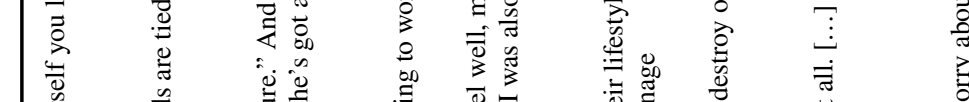

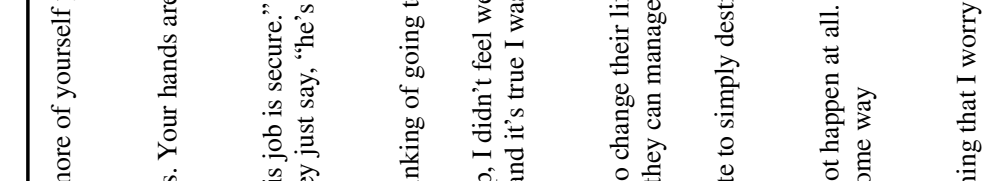

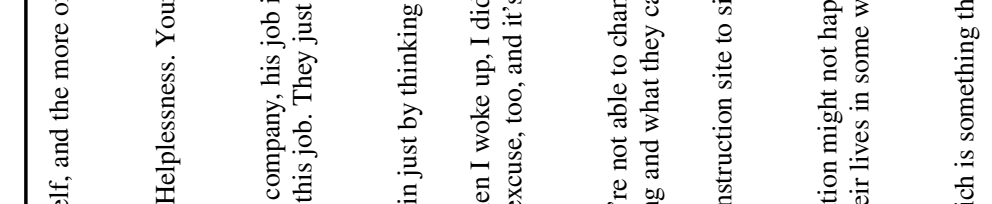

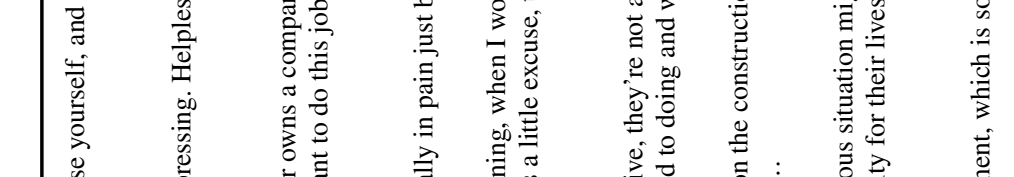

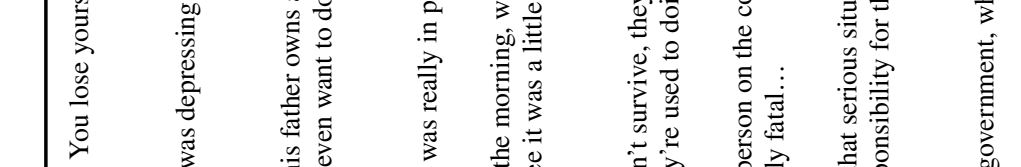

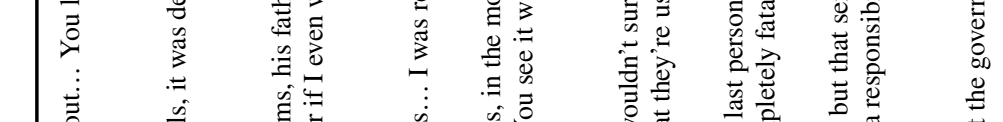

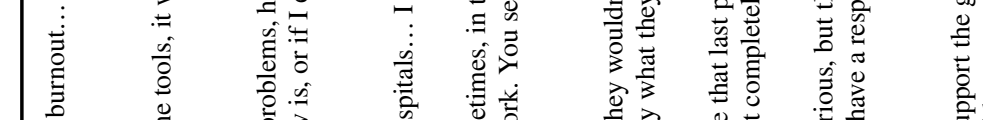

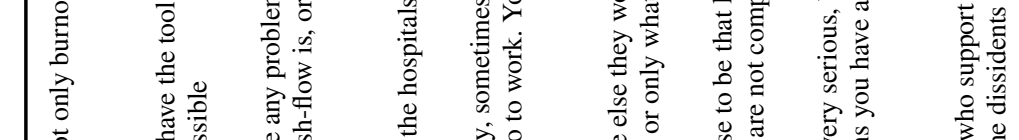

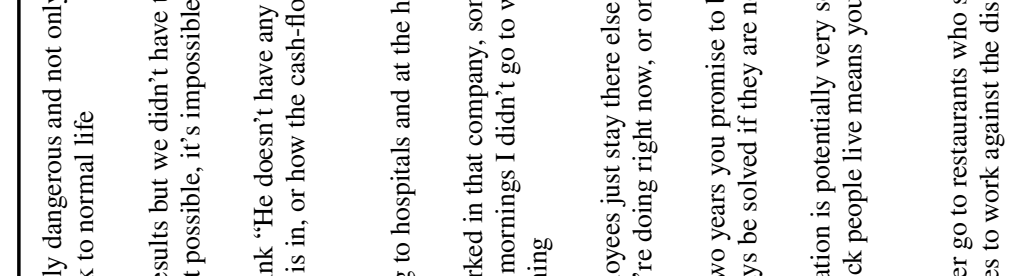

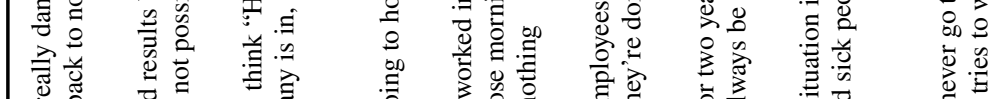

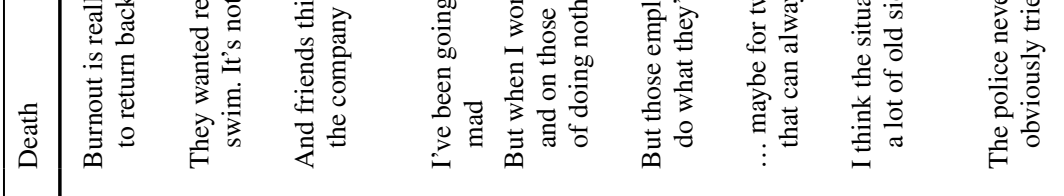

$$
\begin{aligned}
& \text { औी }
\end{aligned}
$$

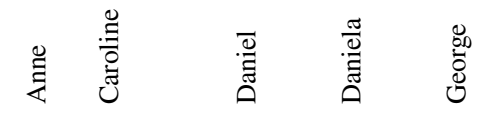

$$
\begin{aligned}
& \text { 高 }
\end{aligned}
$$




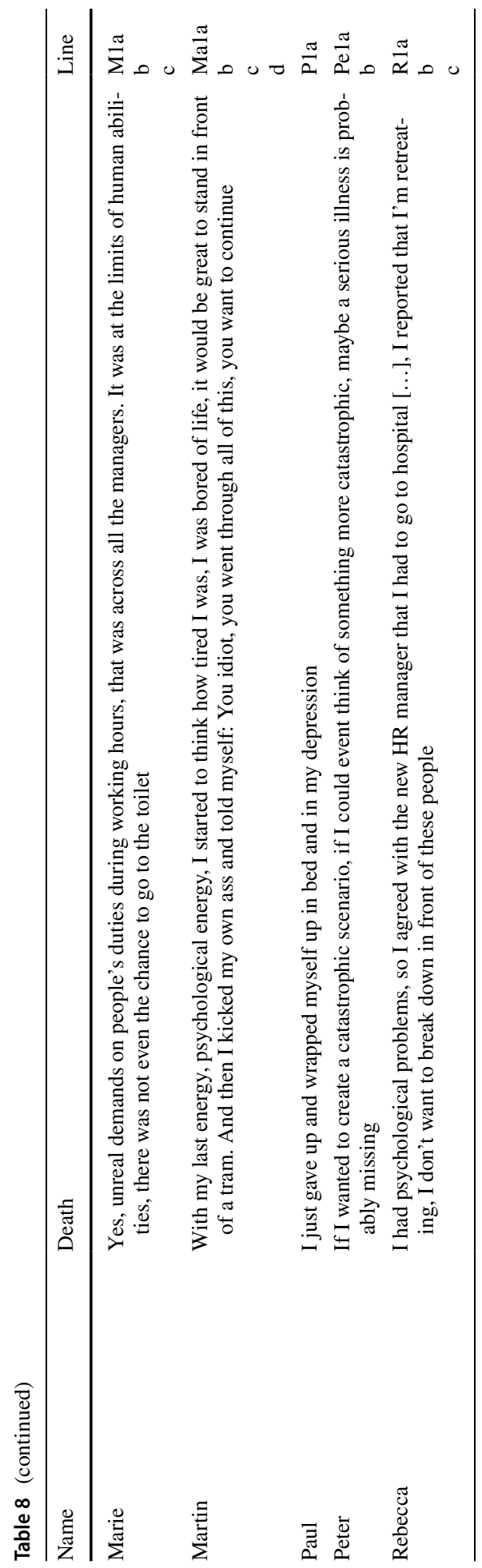


Lack of social support (Table 8: P1a, Pe1a-b) and strenuous work without adequate resources (Table 8: M1a-c) in some cases escalated mental and health problems that lead to hospitalization (Table 8: An1a-c, Ma1a-d, R1a-c). It is precisely this situation that can be described as a moment in the reward of one's own finiteness.

Paul also realized the importance of finiteness through experiments associated with consuming forest plants that trigger a hallucinogenic state. In one such state, he experienced an intense experience with the finiteness of his existence. Like the real existential disruptions associated with work and its relationships, this moment has made him live more authentically.

Overcoming the fear of death and realizing the finiteness of human existence is also used in existential psychotherapy. Clients who are able to work with the awareness of finiteness gain new energy in life and are able to make fundamental life changes (Yalom, 1980, 2008).

The phenomenon of death is one of the central themes in philosophy in general, in the case of the mentioned phenomenologists in particular. It is present in every act of ours, even if we are not fully aware of it (Fink, 1979), mainly because man considers the fidelity of the debate about death to be tactless and rude. Death is not "talked about" (Heidegger, 2001). Death is still perceived as something negative. This threat of death may lie in wait in the future, for example in the context of social change, when democracy advocates will be silenced (Table 8: K1b-c). Death is fatal, and in contrast, we realize that we can somehow affect everything else (Table 8: Da1b-c). It is directly associated with feelings of anxiety out of nowhere. The word "nothing" appears in a number of variations connected with crisis (Table 8: C1d). We often have a literal responsibility for the lives of others, as George, a social worker in a nursing home where COVID-19 is at risk, points out (Table 8: G1c-d). Yet it is possible to find a positive effect on death or our finitude. Patočka sees the awareness of finiteness as the only way to go from the second to the third movement of existence and be authentic (Patočka, 1998). According to Fink, death makes sense of our co-existence with others. Thanks to this, we understand time, and thanks to this, we exist as a project; we can plan and want something precisely because we only have limited time available. Infinite duration would make all desire and all effort to plan completely meaningless. Infinity is a kind of engine of history; it forms the history of human existence. Only a being who exists with the consciousness of his own finiteness can gain the impulse to act immediately from the passage of time (Fink, 1979).

\section{Third Movement of Existence}

The existential situation of the third movement is connected with being released from the inauthentic experience of the managerial role. According to Patočka (1999), it is about becoming a complete human being by getting out of anonymity. Our certainties are shaken. A crisis is what helps managers question assumptions (Rolfe et al., 2016, 2017) and make important decisions. It should be mentioned that this full awareness of existence - authentic being - is not a permanent state. The manager can fall back into new critical situations and return to the second movement. Odiorne (1966) states that the existential manager is a Sisyphean hero who is confronted with ever new problems. Despite this fact, we can imagine a happy manager (similarly to Camus imagining a happy Sisyphus - see Camus, 1979), because at the same time, in Camus's words, the manager is a revolting person who resists difficult conditions strengthened by experiencing the crisis. With this determination, they are able to redescribe 
their crisis and make new decisions that will allow them to stay at the company or to leave it and face new challenges in another work environment. The successful manager knows that they will have other difficult moments ahead of them and that absurd conditions cannot be overcome by an irrational leap towards an idealized future (Müller, 2021a). In this section, we show how managers made sense of their critical moments. Three groups of meanings in the crisis are shown in Fig. 1.

\section{Redescription, Making Sense of Crisis, and Liberation Through Rediscovering Co-existence}

The first common significance of a critical situation is understanding it as a life-changing opportunity and the chance to discover new values related to people and planet. Although Alex evaluates her managerial career as a success, she admits that this work did not make much sense to her. Now she wants to use the experience she gained through the crises she experienced to "help other people on their way of life to have their personality and career balanced". She has started coaching and helping people who have experienced burnoutlike conditions. Alex points out an important idea. Managers believe that if they are not part of the corporation, "they will be nothing". Although he wants to change his job that reduces him to a mere role in the company, he is unable to do so. In addition, the environment confirms that it is a good and well-paid job. The outgoing manager must overcome this difficult feeling and the pressure from the environment. Alex has also begun meditating and developing the spiritual dimension of person.

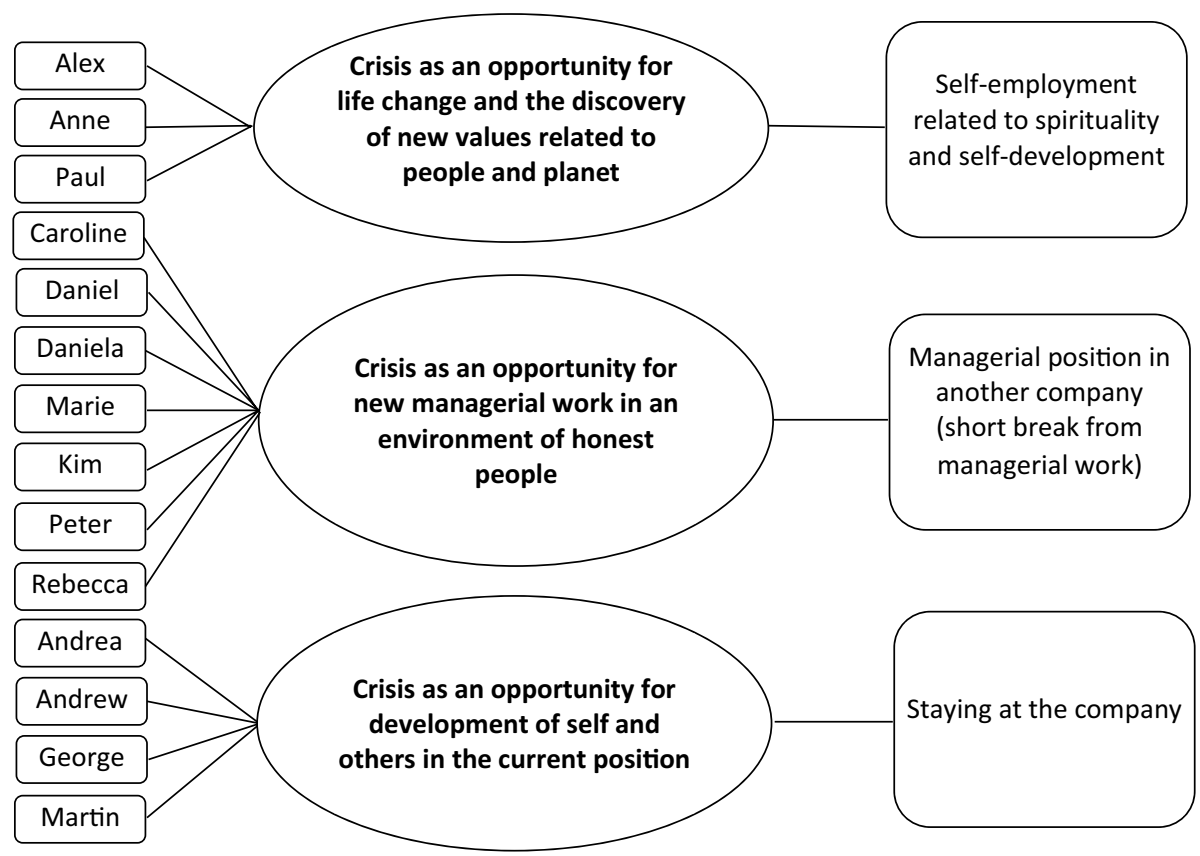

Fig. 1 Making sense of personal crisis 
Anne also managed to overcome this pressure from the environment, realizing that "life is pretty simple, and we just need to follow what we want, and this is life actually", that "life is just doing what you want in the moment to do". Anne is convinced that if people followed what they wanted more often and lived a life together in society, then it would lead to greater love for each other and also for the planet. Anne has begun to deal with spiritual issues and meditations.

Paul mentions that critical situations "were the most important moments" because they led to "internal changes". Paul says he understood that he did not want "to sell my body, my mind, my everything for the money". Questioning the mechanisms of thought he experienced was associated with a long journey of personal development connected with spiritual experiences - a stay in absolute darkness, meditation, and rituals. Paul mentions that the interview with the author of this research was also important for him, as he had the opportunity to describe his life story and reflect on it. Paul is now opening a tearoom where he wants to connect his interest in business with the spiritual dimension and at the same time create a place for people to meet.

Another sense that managers have given to critical situations is the opportunity for new managerial work at another company. It is primarily a desire to work in the company of people who can build fully fledged working relationships and are honest in their actions. Caroline ceased to see her work as meaningful, informed the business owner of his inappropriate behaviour, and left the company.

Daniel describes the realization that he must leave as follows: "So the fear prevailed... or not the fear, but probably the reason, because I saw that if I did, I would actually only hurt myself if I stayed there". He describes his resignation as an "absolutely relaxing feeling". Daniel started working as a marketing manager at a company with great moral awareness that takes care of all areas of sustainable development. Daniela describes that at certain moments in time, she had to change her job. She left the family business mainly due to the mix of family and company roles. Another deeper crisis was associated with the feeling that it was no longer possible to move anywhere and began to feel burnout approaching. However, Daniela summarizes her managerial career by stating that "each stage had its meaning, without which I would not be where I am".

Although Marie remains in her managerial position for the time being, she is looking for other opportunities in other companies that would allow her further development. "Money is not on the first place for me. Most important is that I need to enjoy the job, I need to feel I am useful". She is also constantly learning to build relationships with people and communicate. "I thought self-critically that I would be able to adapt more quickly in terms of the way I communicate with people, but it is an incredible problem for me".

Kim hopes for better job satisfaction. She longs for a job that would be meaningful and associated with greater responsibility. "I hope that my identity could be something bigger, that I could solve problems on my own, take greater responsibility". It was the feelings associated with the need to deal with the crisis that led to the situation where Kim felt like a manager. However, her inability to present herself, her views, and political beliefs eventually led her to leave her job, as well as to move from Hong Kong. She begins a new life with her husband in the Netherlands.

Peter began to question his position as an academic, researcher, and project manager. "Is it really necessary to create psychological pressure on myself to create something"? Broken ties between people, chaos, and uncertainty led him to accept work in education. He feels his social status has improved and is able to make money without degrading pressure from society. He finds his identity in universal humanity. "It is my vision of a universal humanity scholar. I have this vision and I always said that I have nothing else in the world 
than education, or somebody says cleverness, it's such a bad word, but it is the field in which I am competent - the humanities".

Rebecca describes how difficult situations helped her to be stronger. She is proud that she managed them, despite the fact that she did not have any support from her family. "I consider it positively, I am happy I managed to get over a lot of hard situations, and this is not over. I am going to be in productive age for a long time and I am going to work, so many such situations are going to appear". She is ready to face new challenges.

Another way that managers made sense of a crisis was to see the crisis as an opportunity to develop themselves and others in the same position. Andrea wants to change jobs because she feels she cannot grow any further - as if she is stuck in place. She wants to educate herself and the people around her. "I want to be a specialist in what I'm doing, so I should hold on and work hard. I've told myself that I may change my job just once more, but I want to educate myself in what I'm doing and to teach other people. Because it feels great to pass on these experiences and to see people around me rising. And I think that this is the sense of managerial practice".

Andrew sees a great opportunity in the possibility of a new experience. "I understand it as an experience, I can see for myself how a family company of sixty to seventy employees really works". He himself wants to continue his studies at university and develop. He is still learning how to build relationships with colleagues. "I'm usually in situations where I need to communicate with people that are forty to fifty years old, they've been working at the company for ten years, so I have to justify my position. I find that uncomfortable, but I consider it as a positive".

Despite the crises, George wants to stay in his position as a manager. "I like the responsibility of finally getting involved in how things work, how we solve problems, that I can be the person holding the steering wheel and not just the one sitting in the back seat". He continues to look for ways to improve communication and relationships in the workplace, which are atypical due to the unequal numbers of men and women. He also seeks to free himself from the influence of excessive centralized management. "I like that I have a chance to improve some things, but on the other hand I realize that there is a bit of disappointment in that identity, that the leader is far more controlled than an regular worker".

Martin reconsidered his priorities and see gaining valuable experience as more important to him than money. "I said to myself that if someone does business only for money it will destroy them". He is also aware of the importance of human relationships and the importance of the present moment. "It is about our ability to create our future where we can live in ten years. I am fulfilled by this way, by what I do right now". Even managers are aware that "generosity towards the future lies in giving all to the present" (Camus, 1956, p. 304).

\section{Implications for Managerial Self-development}

A qualitative insight into the complex structure of interpersonal relationships helps understand the dynamics of the individual roles that people play in society. However, existential approaches to management show that individuals cannot be reduced to these specific roles but must be treated as complete human beings. We live in a time when more and more educated people have the opportunity to be given a managerial position that is associated with difficult decision-making situations, constant problems, and great responsibility. Not everyone given management education has the disposition to be a manager. Research 
shows that a person becoming a manager is a constant process (Havermans et al., 2019; Hill, 2003; Park \& Faerman, 2019; Segal, 2014, 2017). The essential characteristic of a manager is overcoming critical situations that disrupt established mechanisms and represent new challenges. In many cases, these situations are associated with difficult mental states. If the manager is unable to develop coping skills - questioning no longer valid assumptions and redescribing the experience - these conditions can lead to burnout or other serious health and social problems. This research has shown that there are disparities between the desired role of the manager in society and the perceived identity of the person. It is this phenomenon that requires more attention from occupational psychologists, as appropriate intervention during the process of becoming a manager can prevent serious problems. It is significant for managers to learn to use existential disruptions in their lives as opportunities for self-development. This is illustrated in the following model.

\section{Existential-hermeneutic Model of Self-development}

The research findings help to show how managers achieve self-development through the redescription of their lived experiences, which can be outlined in the extended self-development model (Müller, 2021b). The model of self-development, which is based on the work of Nesbit $(2012,2013)$ supplemented by the findings of our research, is shown in Fig. 2. The process of selfdevelopment can be divided into two basic phases, namely the self-understanding phase and selfchange phase. The self-understanding phase refers to the manager's ability to understand himself

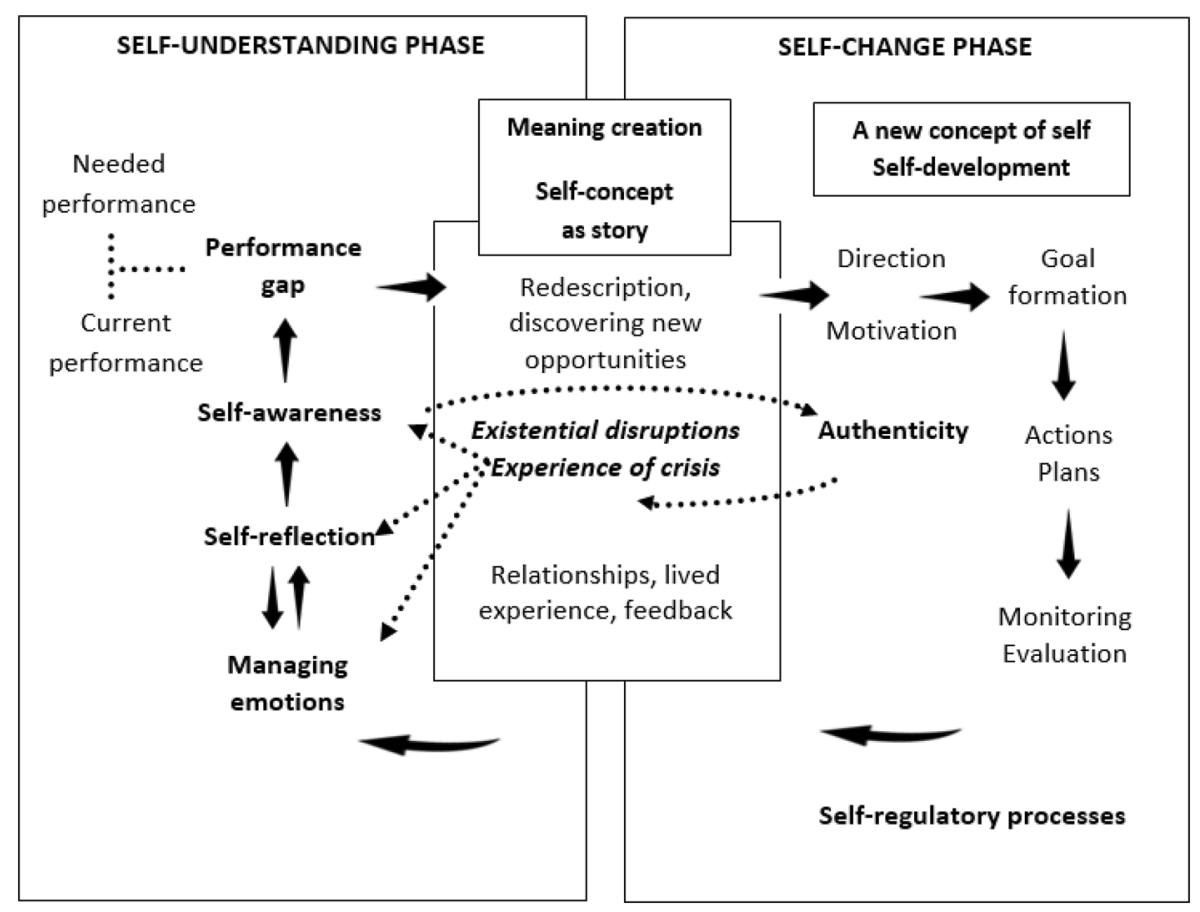

Fig. 2 An extended model of managerial self-development. Source: Adapted from Nesbit (2012, 2013) and supplemented by existential disruptions, the experience of crisis, and meaning-making process 
or herself. This understanding leads to the definition of the so-called performance gap, which defines the difference between current performance and desired performance. In this respect, selfdevelopment can then be seen as a process of evolving from the current level to more complex ways of managerial work. The second phase is concerned with achieving this change (Nesbit, 2013, p. 538).

Our model is characterized by the addition of existential disruptions and critical moments that play a significant role in self-awareness, self-reflection, and the reaching of authentic experience. The process of self-development as we present it is hermeneutic in the sense that the manager's prior understanding of self encounters - during existential disruptions - an experience that does not correspond to this conception of self. There is a recognition of the limits of one's own being as a manager and a definition of the managerial performance gap. It is the lived experience that is significant for this new understanding of self. Managers make meaning of their lived experience, which is put into stories. As McLean et al. (2007, p. 262) show, there is growing empirical evidence for a link between storytelling and self-development. It is stories that are at the core of personal stability and change, and they are particularly influential in shaping self-concept and perceptions of one's own life story. McLean et al. (2007, p. 263) show that through situated storytelling, one develops and maintains both a life story and a self-concept. Self-concept can be understood as beliefs about the self, which can take descriptive or evaluative forms. Aspects of self-concept can include, for example, self-esteem or beliefs about one's own abilities. The life story can then be understood as a second domain of self-concept (McLean et al., 2007), which is an extended, selective autobiography of personal experiences, as well as an interpretation of those experiences. The life story provides unity and meaning to a given person (McAdams, 1993). Our research has shown how making sense of crisis leads to a new conception of self, resulting in self-development for managers.

The development of important interrelated skills is significant to the very success of the self-development process. These are self-reflection, self-awareness, and self-regulation (Nesbit, 2013). In the context of our existential approach, we relate self-awareness to the concept of authenticity.

The self-development of the managers whose stories were analysed in this thesis was primarily concerned with their ways of being a manager. It was about embracing the managerial job with all that goes with it - including the challenges. One level of problems was the acceptance of patterns of behaviour that did not allow the actual process of meaning-making to begin. The second major obstacle was problems in interpersonal relationships. In a situation where experienced ways of working - and experiencing existential disruptions - were disrupted, these problems surfaced. The critical situations associated with existential disruption are significant in several ways:

1. They lead to the questioning of assumptions.

2. They open up space for greater self-awareness and the possibility of being authentic.

3. They initiate a new process of meaning-making.

4. They encourage the redescription of experience.

These processes lead to a new self-concept and the ability to successfully regulate oneself and achieve change. Andrea decided to exchange an approach based on passion and enthusiasm for professionalism gained through education and self-development. She no longer wants to change positions but to specialize in an area she will be good at. This approach means a big change in the way she looks at work and her life. Paul has come to a more authentic way of 
living through the experience of finitude. Paul is now able to be aware of situations where he is reverting to old habits. He is working on being able to recognize and respond to these situations. Peter has realized the importance of self-worth - his identity, which is not just linked to success within projects. Now his self-development is based on wanting to develop himself further, not just because his environment expects it and project activities require it. In the same way, Alex and Anne have found their value outside of managerial work. They have realized that a person's importance cannot be reduced to their job role. Marie and Martin recognized their performance gap in building interpersonal relationships. Marie realized her performance gap in dealing with people. Martin, like Paul, came to recognize that money did not determine his personal worth and came to recognize his need for social support. Rebeca also realized the importance of relationships in her personal life as a support for her managerial work. Daniela and Andrew discovered that their managerial work was influenced by expectations from their parents. While Daniela assessed that it would be best for her personal growth to leave the family firm background, Andrew sees opportunities for growth in the family firm - at least in the short term. Kim and Caroline are looking for a management position that will allow them to feel more like a manager. In Kim's case, there was a realization that one cannot perform one's job role in terms of neutrality. It is the non-anonymous contact with other people that often results in the expression of espoused values and becomes a political act.

\section{Future Research - the Need for an Existential Manager as a VUCA Leader}

Research findings suggest that high demands are placed on contemporary managers to navigate an uncertain world. This complex world is well described by the concept of VUCA volatility, uncertainty, complexity, and ambiguity - which was developed in the context of the need for strategic and military planning. The usefulness of the VUCA concept in the business domain was introduced by Johansen $(2009$, p. 2), who shows that "the future will also be loaded with opportunities" and that "leaders must have the skills to take advantage of those opportunities, as well as the agility to sidestep the dangers". It is the positive importance of uncertainty that is often overlooked in the context of dramatic problems, but uncertainty is important for both opportunity and freedom (Müller, 2021c).

Managers who learn to work with existential disruptions and redescribe them as opportunities become existential leaders. We can recognize the connection between how Kelly and Kelly (1998) describe the existential leader and the concept of VUCA 2.0. by George (2017). Kelly and Kelly describe the existential leader as a charismatic visionary who must have an understanding of the situation of the organizing, be able to work with contradictions and different dilemmas, and last but not least be able to face ambiguity. Similarly, VUCA 2.0 talks about the ability to work with a vision, understanding the organization and its capabilities, having the courage to tackle challenges and having the ability to adapt to a changing environment. Future qualitative research could identify key characteristics of managers facing volatility, uncertainty, complexity, and ambiguity in the context of their being an existential manager. Our research has shown that a key capability is to rewrite a crisis as an opportunity and attribute meaning to it.

\section{Limits of Research}

It is impossible to read this article "technically" without following its existential depth regarding the specific situation of the managers of this research and the language through which the managers express their ideas. The methodological approaches chosen - interpretive 
phenomenological analysis and existential hermeneutic phenomenology - are based on an attempt to intimately capture the lived experience of the participants. The research participant is essentially a co-author of the manuscript, as it is his or her experience that shapes the final outcome of the researcher's work. The words chosen in the manuscript and the interpretive framework developed by the authors reflect precisely the experience of the managers in question. The managers whose lived experience is included in the research realize during existential disruptions, when they question their identity as a manager and when the traditional methods of working that they have used cease to work, that their relationship with their environment is not what they would expect from their nature. On a technical reading of existential ideas, and with knowledge of ordinary managerial work, the idea that managers are plagued by being approached only through their role, which does not include their full being, can come across as "naive". However, it is not that managers are not treated as human beings but that managers feel that there is something missing in the approach to them and that they are not able to perform in the fullness of their potential and in the purity of their imaginings, which are an important stimulus to the meaning-making process that shapes the manager's self-concept, because of the constraints they face.

In reading this article, it is important to bear in mind another limitation of the chosen methodological approach. The article does not present a generalization about the general situation of managers and about managerial work in general. It does, however, provide insight into the lived experience of managers who experience specific critical states associated with questioning their being a manager. Not every manager, although experiencing problems and difficult situations at work, feels an existential disruption - a situation characteristic of the participants in this research - that is very close to the more serious state of burnout. These people had problems with interpersonal relationships that made it impossible to engage social support as one of the basic strategies for preventing burnout. However, their capacity for redescription was strong enough that they stimulated the meaning-making process and were able to use the situation as an opportunity.

Although some managers and management academics may find this philosophical approach distant and may find it difficult to imagine the practical implications of research based on existential hermeneutic phenomenology, we believe that for practitioners and theorists seeking an alternative approach to understanding themselves and their place in the world, this type of research provides inspiration for self-development. Many of the research participants commented on the contribution of the interviews with the researchers to their reflections on managerial work.

\section{Conclusion}

The managers whose life stories were included in this study make sense of personal crisis in three ways. The first type of meaning is based on the redescription of crisis as an opportunity for life change. This change refers in particular to organizing work life in such a way that new values can be discovered and relationships with other people can be developed. It is an approach that respects not only the value of human life but also our planet as a whole. Managers with this sense of managerial work have a strong need for self-development and are interested in their spiritual development. The second way of redescribing the crisis is to see it as an opportunity to change the managerial position. The meaning of this change derives from an understanding of the importance of interpersonal relationships. Managers 
want to work in dignified conditions in ethically responsible companies. The third sense of crisis is formed in the context of using the development potential of the current managerial position. Managers are convinced that experiencing existential disruptions will enable them to achieve self-development. They also consider this development important in the context of training other colleagues and subordinates.

It has been shown that the manager is to be understood as co-existence. A manager's identity and self-concept are formed in the context of interpersonal relationships. It is through others that the manager relates to the world and to himself or herself. Research has shown that the most common categories within which managers describe disruption in interpersonal relational relationships are work, struggle, play, love, and death.

The research findings helped to extend the model of the managerial self-development process to include the lived experience of existential disruptions, which plays a significant role for self-reflection and self-awareness. At the same time, crisis is important for initiating a new process of meaning-making. The formation of the manager's life story is crucial for self-concept. Positive redescription of the crisis and the presentation of one's own experience in dialogue with others are prerequisites for self-regulation processes leading to improved performance. On an existential level, this improvement is related to stepping into the third movement of existence and striving to fulfil the potential of humanity. This refers above all to the rediscovery of co-existence. Participants in our research aspired to a place in ethically responsible societies, wanting to participate in increasing social justice, solving environmental problems, or educating others.

Funding The authors disclosed receipt of the following financial support for the research, authorship, and publication of this article: This article was supported by the Ministry of Education, Youth and Sports of the Czech Republic within the project IGA_FF_2020_012 "Qualitative research of critical moments of managerial practice" of the Palacký University Olomouc.

\section{Declarations}

Conflict of Interest The authors declare no competing interests.

\section{References}

Arendt, H. (2018). The human condition. The University of Chicago Press.

Bolle, E. (2006). Existential management. Critical Perspective on International Business, 2(3), 259-268.

Campbell, N. S., Perry, S. J., Maertz, C. P., Allen, D. G., \& Griffeth, R. W. (2013). All you need is ... resources: The effects of justice and support on burnout and turnover. Human Relations, 66(6), $759-782$.

Camus, A. (1956). The rebel: An essay on man in revolt. Vintage Books.

Camus, A. (1979). The myth of Sisyphus. Middlesex; New York; Victoria; Ontario; Auckland: Penguin Books.

Cunliffe, A. L. (2002). Reflexive dialogical practice in management learning. Management Learning, 33(1), 35-61.

Fink, E. (1969). Metaphysik und Tod. Stuttgart; Berlin; Köln; Mainz: W. Kohlhammer Verlag.

Fink, E. (1979). Grundphänomene des menschlichen Daseins. Freiburg; München: Hg. v. E. Schütz u. F.-A. Schwarz.

Fink, E. (1992). Natur, Freiheit, Welt. Philosophie der Erziehung. Würzburg: Königshausen \& Neumann.

Fink, E. (2003). Nietzsche's philosophy, Translated by Goetz Richter. London; New York: Continuum.

Fink, E. (2016). Play as symbol of the world. Indiana University Press.

Fry, L. W. (2003). Toward a theory of spiritual leadership. The Leadership Quarterly, 14(6), 693-627. 
George, B. (2017). VUCA 2.0: A strategy for steady leadership in an unsteady world. HBS Working Knowledge. Forbes. https://www.forbes.com/sites/hbsworkingknowledge/2017/02/17/vuca-2-0-a-strategyfor-steady-leadership-in-an-unsteady-world/?sh=734e898613d8

Harlos, K. (2010). If you build a remedial voice mechanism, will they come? Determinants of voicing interpersonal mistreatment at work. Human Relations, 63(3), 311-329.

Harvey, P., \& Harris, K. J. (2010). Frustration-based outcomes of entitlement and the influence of supervisor communication. Human Relations, 63(11), 1639-1660.

Havermans, L., Van der Heijden, B. I. J. M., Savelsbergh, C., \& Storm, P. (2019). Rolling into the profession: Exploring the motivation and experience of becoming a project manager. Project Management Journal, 50(3), 346-360.

Heidegger, M. (2001). Being and time. Blackwell Publishers.

Helms Mills, J., Thurlow, A., \& Mills, A. J. (2010). Making sense of sensemaking: The critical sensemaking approach. Qualitative Research in Organizations and Management, 5(2), 182-195.

Hill, L. A. (2003). Becoming a manager: How new managers master the challenges of leadership. Harvard Business Review Press.

Holt, R., \& Cornelissen, J. (2014). Sensemaking revisited. Management Learning, 45, 525-539.

Jedličková, L., Müller, M., Halová, D., \& Cserge, T. (2021). Combining interpretative phenomenological analysis and existential hermeneutic phenomenology to reveal critical moments of managerial lived experience: a methodological guide. Qualitative Research in Organizations and Management. https:// doi.org/10.1108/QROM-09-2020-2024

Johansen, B. (2009). Leaders make the future: Ten new leadership skills for an uncertain world. BerrettKoehler Publishers Inc.

Kelly, J. \& Kelly, L. (1998). An existential-systems approach to managing organizations. Greenwood Publishing Group.

Langenberg, S., \& Wesseling, H. (2016). Making sense of Weick's organizing. A Philosophical Exploration. Philosophy of Management, 15(3), 221-240.

Laverty, S. M. (2003). Hermeneutic phenomenology and phenomenology: A comparison of historical and methodological considerations. International Journal of Qualitative Methods, 2(3), 1-35.

Leavitt, H. J. (2003). Why hierarchies thrive. Harvard Business Review, 81(3), 96-102.

Lee, H., \& Cummings, G. G. (2008). Examining relationships between director leadership practices and manager worklife and burnout. Journal of Leadership \& Organizational Studies, 2(2), 47-62.

Leiter, M. P., \& Maslach, C. (2005). Banishing burnout: Six strategies for improving your relationship with work. John Wiley \& Sons.

Mackie, K. S., Holahan, C. K., \& Gottlieb, N. H. (2001). Employee involvement management practices, work stress, and depression in employees of a human services residential care facility. Human Relations, 54(8), 1065-1092.

MacMillan, S., Yue, A. R., \& Mills, A. J. (2012). Both how and why: Considering existentialism as a philosophy of work and management. Philosophy of Management, 11(3), 27-46.

Maitlis, S., \& Sonenshein, S. (2010). Sensemaking in crisis and change: Inspiration and insights from Weick (1988). Journal of Management Studies, 47(3), 551-580.

Maslach, C. (2017). Finding solutions to the problem of burnout. Consulting Psychology Journal: Practice and Research, 69(2), 143-151.

Maslach, C., \& Goldberg, J. (1998). Prevention of burnout: New perspectives. Applied \& Preventive Psychology, 7(1), 63-74.

McAdams, D. P. (1993). The stories we live by: Personal myths and the making of the self. Guilford.

McLean, K. C., Pasupathi, M., \& Pals, J. L. (2007). Selves creating stories creating selves: A process model of self-development. Personality and Social Psychology Review, 11(3), 262-278.

Michaelson, C., Pratt, M. G., Grant, A. M., \& Dunn, C. P. (2013). Meaningful work: Connecting business ethics and organization studies. Journal of Business Ethics, 121(1), 77-90.

Müller, M. (2019). What are Existential Disruptions in Managerial Practice? Overcoming Disruptions as Prevention of Burnout. In Talášek, T., Stoklasa, J., Slavičková, P. (Eds.). KNOWCON 2019, Knowledge on Economics and Management: Profit or Purpose (pp. 181-187). Olomouc: VUP.

Müller. M. (2021a). Albert Camus and Management: Opening the discussion on the contributions of his work. Philosophy of Management, 20(4), 441-456.

Müller, M. (2021b). Kvalitativní výzkum kritických momentů manažerské praxe v kontextu existenciálních př́stupů $k$ seberozvoji. Unpublished $\mathrm{PhD}$ diss. Olomouc: Palacký University Olomouc.

Müller, M. (2021c). The value of work-related Uncertainty: Changes from demands on certainty to finding ways of living in uncertainty. Changing Societies \& Personalities, 5(3), 372-388. 
Müller, M., Halová, D., Jedličková, L., \& Cserge, T. (2021). Existential disruptions of managers as a collapse of childhood patterns: An interpretative phenomenological investigation. Integrative Psychological and Behavioral Science. https://doi.org/10.1007/s12124-021-09662-4

Müller, M., \& Jedličková, L. (2020). Several notes on the Existential Hermeneutic Phenomenology for project management and possibilities of its extension by other existential concepts. Project Management Journal, 51(4), 452-463.

Müller, M., \& Kubátová, J. (2021). Existential Values and Insights in Western and Eastern Management: Approaches to Managerial Self-Development. Philosophy of Management. https://doi.org/10.1007/ s40926-021-00184-y

Nesbit, P. L. (2012). The role of self-reflection, emotional management of feedback, and self-regulation processes in self-directed leadership development. Human Resource Development Review, 11(2), 203-226.

Nesbit, P. L. (2013). Managerial self-development: A self-directed approach to developing managerial talent. In Harmsworth, F. (Ed.). Australian Master Human resource Guide. 10th Edition (s. 535-552). CCH Editors.

Odiorne, G. S. (1966). The management theory jungle and the existential manager. The Academy of Management Journal, 9(2), 109-116.

Park, H. H., \& Faerman, S. (2019). Becoming a manager: Learning the importance of emotional and social competence in managerial transitions. The American Review of Public Administration, 49(1), 98-115.

Patočka, J. (1998). Body, community, language, world. Carus Publishing Company.

Patočka, J. (1999). Heretical essays in the philosophy of history: Essays, meditations, tales. Open Court Publishing Co.

Pratt, M. G., \& Ashforth, B. E. (2003). Fostering meaningfulness in working and at work. In K. Cameron, J. E. Dutton, \& R. E. Quinn (Eds.), Positive organizational scholarship: Foundations of a new discipline (pp. 308-327). Berrett Koehler.

Rolfe, B., Segal, S., \& Cicmil, S. (2016). An existential hermeneutic philosophical approach to project management. Project Management Journal, 47(3), 48-62.

Rolfe, B., Segal, S., \& Cicmil, S. (2017). The wisdom of conversations: Existential hermeneutic phenomenology (EHP) for project managers. International Journal of Project Management, 35(5), 739-748.

Rorty, R. (1989). Contingency, irony, and solidarity. Cambridge University Press.

Sandberg, J., \& Tsoukas, H. (2014). Making sense of the sensemaking perspective: Its constituents, limitations, and opportunities for further development. Journal of Organizational Behavior, 36(S1), S6-S32.

Sandberg, J., \& Tsoukas, H. (2020). Sensemaking reconsidered: Towards a broader understanding through phenomenology. Organization Theory. https://doi.org/10.1177/2631787719879937

Segal, S. (2010). A Heideggerian approach to practice-based reflexivity. Management Learning, 41(4), 379-389.

Segal, S. (2014). Business feel: Leading paradigm shifts in organisations. Palgrave Macmillan.

Segal, S. (2017). The existential dimensions of the paradox of becoming in the process turn in organisation studies. Management Learning, 48(4), 471-486.

Smith, J. A., Flowers, P., \& Larkin, M. (2009). Interpretative phenomenological analysis: Theory, method and research. SAGE.

Sveningsson, S., \& Alvesson, M. (2003). Managing managerial identities: Organizational fragmentation, discourse and identity struggle. Human Relations, 56(10), 1163-1193.

Van der Hoorn, B., \& Whitty, S. J. (2015). A Heideggerian paradigm for project management: Breaking free of the disciplinary matrix and its Cartesian ontology. International Journal of Project Management, 33(4), 721-734.

Vandekerckhove, W. (2020). COVID, existentialism and crisis philosophy. Philosophy of Management, 19, $129-132$.

Vandyshev, V. N. (2015). The existential problems of management. Jagiellonian Journal of Management, 1(2), 131-140.

Weick, K. E. (1988). Enacted sensemaking in crisis situations. Journal of Management Studies, 25(4), $305-317$.

Weick, K. E. (1995). Sensemaking in organizations. Thousand Oaks; London; New Delhi: SAGE.

Wong, C. A., \& Spence Laschinger, H. K. (2015). The influence of frontline manager job strain on burnout, commitment and turnover intention: A cross-sectional study. International Journal of Nursing Studies, 52(12), 1824-1833.

Yalom, I. D. (1980). Existential psychotherapy. Basic Books.

Yalom, I. D. (2008). Staring at the sun: Overcoming the terror of death. The Humanistic Psychologist, 36(34), 283-297.

Publisher's Note Springer Nature remains neutral with regard to jurisdictional claims in published maps and institutional affiliations. 